\title{
Az elidegeníthető birtoklást kifejező -j-képző esete a -(Vt)t főnévképzővel és más főnévképzőkkel
}

\author{
Alberti Gábor \\ PTE Nyelvtudományi Tanszék \\ Farkas Judit \\ MTA Nyelvtudományi Intézet
}

\begin{abstract}
Összefoglaló
Az elidegeníthető birtoklás -j-képzőjéröl (den Dikken 2015) kimutattuk, hogy abban a formában létezik, hogy a magyar főnevek legtöbbjének a fonotaktikai felépítése megengedi egy potenciális reguláris birtokszóváltozat létrehozását, ami az említett -j-komponenst valóban tartalmazza. Mivel azonban a -j-komponenst sok esetben a lexikalizálódott birtokszó-alternatívák is tartalmazzák (vö. ajtója ajtaja), az elidegeníthető birtoklásra vonatkozóan úgy mondhatunk ki hatékony szabályt, ha az a potenciális reguláris birtokszóváltozat fogalmára épül. A főnévképzéshez mindez a következő módon kötődik. Az Amerika felfedezte(kor) és a Péter felfedezettje birtokos szerkezetek között a döntő formai különbség éppen a fent említett, elidegeníthetőségért felelős -j-komponensben rejlik, ami éppen akkor jelenik meg, amikor a birtokos a birtokszó igei tövének Ágense. Általánosítva: az igéböl képzett főnevekre maradéktalanul teljesül a szabály, amelyre fentebb utaltunk, ha az „elidegeníthetőséget” a deverbális fönevekkel alkotott birtokos szerkezetek körében az igei tő és a birtokos ágentív vagy „még lazább” kapcsolatában határozzuk meg (ahol a „szoros” kapcsolatot az ige és a hozzá téma szerepben társuló vonzat viszonya jelenti).
\end{abstract}

Kulcsszavak: magyar birtokos szerkezet, elidegeníthetetlen birtoklás, elidegeníthető birtoklás, fönévképzés, operátorok és hatókörök

\section{Bevezetés}

A címben nevesített -j- és -(Vt)t képző már önmagában is magyarázatra szorul: e két potenciális képzőről szól a 2. és a 3. szakasz, gondosan szerkesztett példabokrokon szemléltetve megközelítésünk lényegét. A 3. szakaszban mutatjuk be azt a jelenséget, amely a cikk alapgondolatát képezi: az Amerika felfedezte(kor) és a Péter felfedezettje birtokos szerkezetek között a döntő formai különbség éppen a fent említett, sokak szerint elidegeníthetőségért felelős -j-komponensben rejlik, ami éppen akkor jelenik meg, amikor a birtokos a birtokszó igei tövének Ágense. A 4. szakaszban rámutatunk, hogy kapcsolódásuk változatai egy a birtoklás szemantikai jellegére vonatkozó univerzálét követnek: a magyarban az igéből képzett főnevek valamennyi típusában teljesül (a 2. szakaszban kimondott) szoros összefüggés (lényegében) a -j-vel képzett alak és az elidegeníthető birtokviszony között, 
amennyiben az „elidegeníthetőséget” a deverbális főnevekkel alkotott birtokos szerkezetek körében az igei tő és a birtokos ágentív vagy „még lazább” kapcsolatában határozzuk meg (ahol a szoros kapcsolatot az ige és a hozzá Téma szerepben társuló vonzat viszonya jelenti). A produktív főnévképzők teljes spektrumán igazoljuk ezen univerzálé teljesülését, megadva az elidegeníthető birtoklás (neo-)davidsoniánus szemantikai reprezentációját, amit az 5 . szakaszban a magyar főnévi szerkezet generatív szintaktikai elemzésében kamatoztatunk. A cikket záró 6. szakasz rövid összegzést nyújt.

\section{Az elidegeníthető birtoklást kifejező -j- morféma}

Den Dikken (2015: 131) egy önálló -j- morféma mellett érvel a birtokoltságra utaló -(j)A toldalékon belül (többek között Kiefer (1985) és Elekfi (2000) megfigyeléseire támaszkodva a hazai szakirodalomból), amit ritkán, morfofonológiai és nyelvtörténeti körülmények szerencsés összjátéka esetén érhetünk tetten. Amikor viszont tetten érhetjük - például abban, hogy a háznak ablaka van (1a), míg egy forgalmazó cégnek ablakja (1a') - olyankor a -j- morfémának a birtoklás elidegeníthetőségének kifejezését tulajdoníthatjuk (Id. alább az (1) vesszős példáit), megerősítve evvel egy plauzibilis univerzálét (Haspelmath 2008), miszerint a birtoklást többféleképpen is kifejezni képes nyelvekben a morfológiai szempontból gazdagabb változat utal az elidegeníthetó birtoklásra, szemben az elidegeníthetetlennel. Kiefer (2000: 201) e fogalmakat a következőképpen határozza meg, szemantikai alapon: „az 'x elidegeníthetetlen része y-nak' azt jelenti, hogy 'x szükségszerüen yhoz tartozik', az 'x nem elidegeníthetetlen része $y$-nak' pedig azt, hogy ' $x$ nem tartozik szükségszerüen y-hoz, x leválasztható y-ról'” (minderről ld. még (Schirm 2005), illetve (Laczkó 2009)). E meghatározást nem kívánjuk ehelyütt pontosítani vagy bővíteni, de megjegyezzük, hogy az elidegeníthetőséghez vagy elidegeníthetetlenséghez társuló morfológiai vagy más formai jegyegyüttesek megléte alapján találhatunk olyan eseteket (pl. a definíció szerint elidegeníthető Imi inge konstrukciót szemben az „egyértelműen elidegeníthető” a világ legszebb ingje konstrukcióval), amelyeket a kiinduló definíció alapján inkább az ellentétes csoportba kellett volna besorolnunk, de a nyelvbe némileg módosult világszemlélet alapján épülnek be. Kiefer (2000: 202-203) is megemlíti, hogy „az elidegeníthetetlenséget általában kiterjesztjük olyan dolgokra is, amelyek valójában elidegeníthetők, de hozzátartoznak az alapszóval jelölt személyhez vagy tárgyhoz"; az iménti példa nyilván ebbe a körbe tartozik.
elidegeníthetetlen birtokviszony
a. a ház ablak(*j)a
b. Dönci has $\left({ }^{*} \mathrm{j}\right) \mathrm{a}$
c. Ági gégé* $(\mathrm{j}) \mathrm{e}$
d. Ili any( *á)ja
elidegeníthető birtokviszony ${ }^{1}$
a'. a világ legjobb ablak??(?)a
b'. a világ legnagyobb has? $\left.{ }^{*} \mathrm{j}\right) \mathrm{a}$
c'. a kórház mesterséges gégé $(j) e$
e. ennek a csavarnak az any*(?)á)ja e'. a szerelő legnagyobb any*('á)ja

${ }^{1}$ Minden változtatás nélkül, eredeti nyelven adjuk meg a Projektben mintaként szolgáló átfogó holland forrásnyelvtan értékelési kategóriáit (Broekhuis-Keizer-den Dikken 2012: viii): *: unacceptable, ${ }^{*}$ ?: relatively acceptable compared to *; ??: intermediate or unclear status; ?: marked: not completely unacceptable or disfavored form; (?): slightly marked, but probably acceptable. 
f. Karesz $\operatorname{kar}^{*}(j) a$

g. az egyetem új $\operatorname{kar}\left({ }^{*} \mathrm{j}\right) \mathrm{a}$

h. a németek császár(*j)a

i. az oroszok cár*(j)a

j. a ház teteje/*tetője

k. a bárány gyapja/* ${ }^{*}$ gyapjúja

I. a városka főtere/º̋térje f'. a kórház mesterséges $\operatorname{kar}^{\star}(? \mathrm{j}) \mathrm{a}$

g'. a világ legjobb bölcsészkar (?)(?j)a

h'. minden idő́k legifjabb császár(?)(?j)a

i'. minden idők legifjabb cár*(j)a

j'. a cég legjobb *teteje/(?)tetöje

k'. a cég legjobb *?gyapja/(?) gyapjúja

I'. a világ legszebb (?)főtere/"?főtérje

Den Dikken (2015) állításának hatálya értelemszerủen nem terjedhet ki például a szibilánsra végződő főnevekre (1b), amelyekhez a magyar fonotaktika törvényszerűségei alapján semmiképpen nem csatlakozhat egy toldalék $j$-vel kezdődő allomorfja (Rebrus 2013: 387, 390), illetve a magánhangzóra végződő főnevekre (1c), amelyek viszont csakis a j-vel kezdődő allomorfot fogadják el (Rebrus 2013: 390). A fent bemutatott (1d) (rokonsági) típusra viszont szabályjavaslattal él den Dikken (2015: 141-142), amelynek lényege abban áll, hogy az e típusba tartozó esetekben történetesen egy -a- toldalék veszi át a -j- toldalék elidegeníthetőbirtokláskifejező szerepét. Az (1f-I) pontokban olyan eseteket mutatunk be (a teljesség igénye nélkül), amelyekröl den Dikken (2015) nem ad számot.

A mi alább ismertetésre kerülő javaslatunk olyan általánosítást fogalmaz meg, amely a fenti (1) példasorba foglalt valamennyi típusra érvényes, számot vetve mind a szinkrón szempontból már csak nyelvtörténeti véletlenek következményének tekinthető jelenségekkel, mind pedig az anyanyelvi beszélők grammatikalitási ítéleteit gyakran befolyásoló hiperkorrekciós hajlamokkal, amiből adódóan megfigyeléseink szerint sokan eleve kategorikusan elzárkóznak a mesterkélten hangzó potenciális -j-s birtokszóváltozatoktól.

Ami ez utóbbi tényezőt illeti, érdemes az adatokra az „Átfogó magyar nyelvtan” projektben elfogadott hatelemú értékelési skálát alkalmazni, hiszen a birtokszóalakok kapcsán is a (magyar) nyelv életlen határait próbáljuk feltérképezni (AlbertiFarkas 2013). A fenti (1) példasorban e cikk két szerzőjének anyanyelvi intuícióját írjuk le, amely szerint például az (1a) pontban szemléltetett elidegeníthetetlen birtokviszony kifejezésére a -j- nélküli változat tökéletes, míg a -j-s változat teljesen elfogadhatatlan - ezt fejezi ki a zárójelben lévő csillag, amely nem társul semmilyen zárójel előtti értékelő szimbólummal. Tekintsük most az (1a') példát az elidegeníthető birtokviszony kifejezésére vonatkozóan. A zárójel két oldalán látható értékelő szimbólumok azt fejezik ki, hogy egyik változat sem kifogástalan (vagy egyértelműen kizárt), de míg a -j-s változat, ha gyengén is, de elfogadható ('?'), a -j- nélküli alulról közelíti az elfogadhatóság minimumát ('??'). A további két értékelő szimbólummal az (1d') pontban lehet megismerkedni: úgy ítéljük meg, hogy az anyája változat az elidegeníthető birtoklás kifejezésében szinte teljesen elfogadható ('(?)'), alig jelez jelöltséget az anyanyelvi intuíció, az anyja változat grammatikalitása viszont a teljes elfogadhatatlanságnál éppen csak egy nagyon finom árnyalattal jobb ('^?').

A fent említett (vélhetően hiperkorrekciós) hatást (miszerint sokan eleve kategorikusan elzárkóznak a mesterkélten hangzó potenciális -j-s birtokszóváltozatoktól, figyelmen kívül hagyva a szövegkörnyezetet) úgy semlegesíthetjük, hogy olyan anyanyelvi beszélöről teszünk állítást, aki számára a -j-s változat valamilyen mértékben elfogadható. Adekvát általánosítást pedig úgy nyerhetünk, ha nem ,,$j-s$ 
változatról” beszélünk, hanem „potenciális reguláris birtokszóváltozatról”. Ez utóbbi hangalak úgy definiálható, mint a szinkrón nyelvállapotban használatos toldalékolatlan főnévi tő toldalékolt változata a (hangrendfüggő) -jA hangsorral:

(2) Amennyiben egy magyar anyanyelvi beszélő számára valamilyen mértékben elfogadható egy főnév potenciális reguláris birtokszóváltozata, azaz legalább '?' ítéletet ad rá, továbbá elfogadható számára a főnév ugyanolyan jelentésében egy másik (lexikalizálódott) birtokszóváltozat is, akkor a potenciális reguláris birtokszóváltozattal alkotott birtokos szerkezethez fog társítani - az imént említett grammatikalitási ítélet mellett - elidegeníthető birtokviszonyt kifejező jelentést.

A (2) szabályt nem érvénytelenítik tehát azok az anyanyelvi beszélők, akik a fenti (1a-a') példapárban bemutatott ablakja alakot, azaz a potenciális reguláris birtokszóváltozatot, kategorikusan elutasítják, és/vagy az ablaka alakot, azaz a lexikalizálódott alternatívát, el tudják fogadni (valamilyen mértékben) az elidegeníthető birtoklás kifejezésében (is). Annyit állítunk, hogy aki valamilyen mértékben elfogadja az ablakja alakot, az elfogadja az elidegeníthető birtoklás kifejezésében is. Azt jósoljuk kizártnak, hogy valaki (az anyanyelvi intuíciója alapján) az ablakja alakot csakis az elidegeníthetetlen birtoklás kifejezésében fogadja el.

Az (1b-b') példapár nem cáfol(hat)ja meg a (2) szabályt, hiszen az annak premisszájában említett „valamilyen mértékben elfogadható potenciális reguláris birtokszóváltozat" egyszerüen nem létezik az anyanyelvi beszélők számára, fonotaktikai okokból adódóan, ahogyan arra fentebb már utaltunk (Rebrus 2013: 387, 390). Az (1c-c') példapár szintén azért vonódik ki a (2) szabály hatálya alól, mert nincsen két versengő birtokszóváltozat; ezúttal csak a potenciális reguláris birtokszóváltozat létezik, szintén fonotaktikai okokból adódóan (Rebrus 2013: 390).

Az (1d-d') esetet azonban külön diszkutálás nélkül kezeli a (2) szabály. Az anyája alak a potenciális reguláris birtokszóváltozat, amely éppen a megjósolt módon áll szemben a lexikalizálódott anyja alakkal. Az (1d') alternatívák esetleg eltérő jólformáltsági megítélése - akárcsak a teljes példasor beszélőfüggő megítélése - tág határok között „összefér” a (2) szabállyal. Gondosan megfogalmazott hipotézisünket csak egészen extrém anyanyelvi intuíciók kimutatásával lehetne cáfolni.

Az anya szó poliszémiájából adódó jelenségek (1e-e') nyilván érdekes kihívást jelentenek a (2) szabály és versenytársai számára: például az a jelenség, hogy az anyája alak az elidegeníthetetlen birtokviszony jelölésében (1e) mintha valamivel elfogadhatóbb lenne (nyilván a könnyebb előhívhatóságból adódóan), mint az elidegeníthetőében (1e'). A (2) szabály úgy védi ki a potenciális problémákat, hogy elhatárolódik a főnév eltérő jelentésváltozatainak összevetésétől. A csavaranya esete tehát egyszerűen nem esik a (2) szabály hatálya alá, hiszen csak a potenciális reguláris birtokszóváltozat létezik, vetélytárs nélkül - irreleváns, hogy melyik birtokviszony-értelmezés mellett milyen elfogadhatósággal.

Vizsgáljuk meg, hogy a kar szó több jelentése milyen következményekkel jár a birtokviszony-értelmezésekre nézve (NB: a testrész jelentésű szó feltehetőleg ótörök eredetű, míg a testületet jelentő szó latin eredetű, a kórus szó rokona - ami nem zárja ki amúgy, hogy a szinkrón nyelvállapotban az anyanyelvi beszélők 
poliszémiát érezzenek, de ennek nincs jelentősége a (2) szabály alkalmazása szempontjából). Első pillantásra furcsának tűnhet, hogy a testrész jelentésű kar éppen a -j-s változatában lép be az elidegeníthetetlen birtokviszony kifejezésébe (1f-f'), míg a testület jelentésű kar a -j- nélküli változatában nyújt kifogástalan birtokos szerkezeteket (1g-g'). Mindez azonban a (2) szabályt egyáltalán nem sérti meg, hiszen a két lexikai egység birtokszóváltozatait nem vetjük össze egymással. A testrész jelentésü kar történetesen -j-s változatban vesz rész az elidegeníthetetlen birtokviszony kifejezésében (1f), ami egybeesik tehát a potenciális reguláris birtokszóváltozattal ( karja), amely alaknak ezek után nem könnyű előhívni az elidegeníthető jelentését sem az (1f') kontextusban, sem az (1g') kontextusban. Az (1g) változat egyébként - „modern jelentése” ellenére - elidegeníthetetlen rész-egész viszonyt fejez ki; de ennek tulajdonképpen nincsen jelentősége a (2) szabályra nézve, mert az csak arról tesz állítást, hogy a potenciális reguláris birtokszóváltozat társulhat elidegeníthető jelentéssel, arról nem, hogy a lexikalizálódott változat milyen jelentést hordoz.

Az (1h-i') példasor azért került be a tárgyalásunkba, mert kihívást jelenthet annak megmagyarázása, hogy a hasonló jelentésű és hangszerkezetű császár és cár szavak miért viselkednek eltérően a -j-felvétele tekintetében. A példapár nyilván cáfolatát jelenti egy olyan erősebb potenciális állításnak, miszerint a -j-felvételét és hiányát egyaránt megengedő mássalhangzó után az elidegeníthetőségi jegy dönt az ominózus -j- felvétele vagy mellőzése mellett. A (2) szabály nem véletlenül fogalmaz tehát óvatosabban. ${ }^{2} \mathrm{Az}$ (1i-i') példák egyszerüen nem esnek a hatálya alá, történetesen nem lévén alternatívája a potenciális reguláris birtokszóváltozatot jelentő cárja alaknak. Az (1h-h') példapárról pedig helyesen állítja a (2) szabály, hogy ha valaki elfogadja a császárja alakot, akkor ahhoz elidegeníthető jelentés kötődik; amibe az is beleértendő azonban, hogy akár a császára alakhoz is rendelődhet elidegeníthető jelentés.

Az (1j-k') példákról kifogástalanul számot ad a (2) szabály, elidegeníthető jelentést jósolva a tetője és gyapjúja potenciális reguláris birtokszóváltozatoknak, anélkül, hogy valamely tartalmazott hanghoz kellene megpróbálni odarendelni az elidegeníthetőség jegyét. $E$ jegyet majd maga a reguláris összerakás hozza magával, amint azt kifejtjük a 4. szakaszban.

A fenti utolsó (1l-I') példapár azt mutatja, hogy esetenként akkor sem létezik a potenciális reguláris birtokszóváltozat, ha annak semmiféle fonotaktikai akadálya nincs. Az adott eset azonban nem esik a (2) szabály hatálya alá, tehát nem sérti meg azt. Ez a példa azonban azt mutatja, hogy egy olyan erősebb szabály, mint amit az alábbi (3) pontban demonstrálunk, csupán tendenciának tekinthető, aminek - kevésbé radikálisan ugyan - az (1g-h') példacsoport (sőt számos beszélő esetében a

\footnotetext{
${ }^{2}$ Cikkünk egy korábbi változatának egyik névtelen kritikusa felveti, hogy legalább a testrészek szükebb csoportjában meg kellene próbálni az imént említett erősebb összefüggést felállítani egyfelől az elidegeníthetőség és a potenciális reguláris birtokszóváltozat, másfelől az elidegeníthetetlenség és egy alternatív lexikai alak között. Ő maga hoz azonban ellenpéldát: az Imi comba konstrukció teljességgel elfogadhatatlan; vagyis mind az elidegeníthetetlen esetben (Imi combja), mind az elidegeníthetöben (a világ legizmosabb combja) ugyanazt a -j-vel képzett birtokosalakot használjuk.
} 
kiindulási pontot jelentő (1a-a') példa is) már az a. pontját megsérti. ${ }^{3}$ A teljes $(3 a-b)$ szabályváltozat egyértelműen csupán a következő esetekben teljesül: (1d, j, k).

(3) a. Amennyiben a magyar nyelv fonotaktikai szabályai nem tiltják meg egy főnév potenciális reguláris birtokszóváltozatának a létrehozását, akkor ehhez a hangalakhoz társul az elidegeníthető birtokviszony kifejezése (b. miközben az elidegeníthetetlen birtokviszony kifejezésére létezik a nyelvben egy ettől eltérő lexikalizált birtokszóváltozat).

\section{A produktív magyar deverbális fönévképzők rendszere}

Kiindulópontunk Laczkó (2000) azon állítása, miszerint az -Ás főnévképző mellett (4b-b') létezik egy, az -Ó melléknéviigenév-képzővel homofon főnévképző is (4c-c'). Mi ehhez azt az állítást tesszük hozzá, hogy a -(Vt)t melléknéviigenév-képző esetében is létezik ilyen homofon főnévképző (4b-b', d-d'); sőt, egy -hatnék főnévképzővel is számolnunk kell (4e-e') a produktív magyar deverbális főnévképzők között.

Az alábbi (4) példabokor a feltáruló rendszeren túl rögtön a következő szemantikai megfigyeléseket is szemlélteti: (i) ha eseményre utal a T-főnév (hasonlóan az ÁS-főnevekhez), akkor tulajdonképpen annak kumulatív időpontjára utal (4b-b'); (ii) ilyenkor preferált az élettelen birtokos (4b-b'); (iii) a T-főnév jelölete személy is lehet (4d'); (iv) tárgy (jellegű entitás) azonban nem (4d); (v) HATNÉK-főnevet (Tompa 1959; 1961; Oszoli 2014) olyan igéből képezhetünk, amelynek alanya Ágens, mint a dolgozik alanya (4e), vagy legalábbis olyan „részleges kontrollt gyakorló” humán szereplö, mint az alább említett tüsszögó (4e), és nem prototipikus Téma (azaz nem prototipikus Páciens; $\left.\left(4 e^{\prime}\right)\right)$.
a. Kolumbusz felfedezte Amerikát.
a'. Péter felfedezte Dórit.
b. Amerika ${ }^{(?)}$ felfedeztével /` felfedezésével új korszak kezdődött.
b'. Dóri ? felfedeztével / ${ }^{\vee}$ felfedezésével Péter életében is új korszak kezdődött.

\footnotetext{
${ }^{3}$ Az osztályozók egy típusában, mint Szabó Veronika felhívta rá a figyelmünket (2015. május 18-án), ugyancsak a potenciális reguláris birtokszóváltozat ad jobb (bár nem kifogástalan) mondatokat: pl. ?Pohárjal?? Pohara 300 forint ennek a bornak. A potenciális reguláris birtokszóváltozat az amúgy szintén elidegeníthető birtoklást kifejező esetben elfogadhatatlan viszont: Ez a talpas pohár ma Jóska pohara/ ${ }^{*}$ pohárja. A nagyon óvatosan megfogalmazott (2) szabályt nem sérti meg e két megfigyelés, hiszen e szabály csak annyit állít, hogy akinek elfogadható a potenciális reguláris birtokszóváltozat, annak a potenciális reguláris birtokszóváltozattal alkotott birtokos szerkezethez társulhat elidegeníthető birtokviszonyt kifejező jelentés (NB: a szóban forgó osztályozó szerkezetet elidegeníthető birtoklást kifejező konstrukciónak tekintjük), azt nem, hogy az elidegeníthető birtokviszonyt kifejező jelentésben kizárólag a potenciális reguláris birtokszóváltozat jelenhet meg. Jövőbeli kutatások tárgyát képezi az elidegeníthetőség fekete-fehér szemantikai fogalmának felváltása egy árnyaltabb skálával, ami a formai alternatívákhoz jobban igazodik (Id. még az (1) példasor előtti gondolatmenetet Kiefer (2000) meghatározása kapcsán). Az árnyaltabb skála azt tenné lehetővé, hogy az Imi inge konstrukciót például „kevésbé elidegeníthetőnek” nyilváníthassuk, mint a világ legszebb ingje konstrukciót.
} 

c. Kolumbusz volt Amerika felfedezője.
c'. Péter volt Dóri felfedezője.
d. *Amerika Kolumbusz felfedezettje volt.
d'. Dóri Péter felfedezettje volt.
e. Meglepődtem Ili leküzdhetetlen dolgozhatnékján/tüsszöghetnékjén.
e'. *?Meglepődtem Ili leküzdhetetlen elfáradhatnékján/lebarnulhatnékján.

A fenti jelentésbeli korlátokra alapozva érdemben felvethető az a hipotézis, hogy az $(V t) t+(j) A$ toldalékcsoport kétféle produktív T-főnévképzésre és egy produktív HATNÉK-főnévképzésre utal, hiszen egy képzés produktivitásának igazolása elsődlegesen a bemeneti tartomány megbízható körülhatárolásán és a kimenet jelentésének kiszámíthatóságán áll vagy bukik (Kiefer-Ladányi 2000a: 149; KieferLadányi 2000b: 166, 186). Kétségtelen ugyanakkor, hogy a 2. szakaszban tárgyalt potenciális reguláris birtokszóváltozat konstrukciójához hasonlóan mindkétféle Tfőnévképzés az anyanyelvi intuíciónk olyan határán mozog, ami a kifogástalan alakoktól az erősen jelölt ('??') potenciális alakokig terjed. Igazolja azonban anyanyelvi kompetenciánk adott területen való müködését a következő megfigyelés (is): bár a (4b') T-föneve - ahogyan a '?' jelzi - kétségtelenül jelölt forma (archaikus benyomást kelt), a fonotaktikailag megengedett változatok közül mégis egyértelműen ezt választjuk, és nem az *Amerika felfedezettjével potenciális alakot; mint ahogyan a későbbiekben sorra kerülő (8e') példában sem használnánk személyre vonatkoztatva az *Ili megmasszírozta potenciális alakot, noha kétségtelenül kissé jelölt az Ili megmasszírozottja változat is. Neologizmusokra is elégséges szinten müködik a kétféle T-főnévképzés és kifogástalanul müködik a HATNÉK-főnévképzés (a felismert jelentésbeli korlátok tiszteletben tartásával): ${ }^{4}$

a. ${ }^{(?)}$ A honlap belájkoltával új korszak kezdődött Jani életében.

b. Jani volt lli tegnapi belájkolója.

c. (?) lli volt Jani tegnapi belájkoltja.

c'. Jani leküzdhetetlen facebookozhatnékjából már sok baj származott.

A produktivitás vizsgálatához hozzátartozik az értelmezési tartomány szemantikai korlátai mellett a fonotaktaktikai korlátok feltárása is. A megfékez (6a') és hazahoz (6b') igék nyilvánvalóan azért vethetőek alá sokkal készségesebben az

\footnotetext{
${ }^{4}$ Vajon a folyamatos melléknévi igenév képzőjével homofon -Ó szuffixum, a befejezett melléknévi igenév képzőjével homofon -(Vt)t szuffixumhoz hasonlóan (Id. felfedezettje / felfedeztével), a „szereplő” jelentésű derivált kifejezésen kívül (például bemondó(ja)) produktívan képez-e esemény jelentésű kifejezéseket is? Van-e tehát ilyen jellegű szimmetria a magyar képzők rendszerében? Laczkó (2000: 390) álláspontja az, hogy „az egyszerű eseményt jelölő Ó-fönevek [például esküvő, találkozó, szalagavató] a mai magyar nyelvben lexikalizálódott alakoknak, tehát nem produktív szóképzési folyamat eredményeinek tekintendők". Alapvetően elfogadva ezt az álláspontot, mi azt találtuk, hogy egy sajátos szerkezettípuson belül igenis felfogható termékenynek az esemény jelentésű Ó-főnevek képzése: bizonyos fajta szóösszetételről van szó. Igazoljuk ezt egy fiktív ige segítségével, ami legyen mondjuk a gorpol! A gorpolósegéd, gorpolókés és gorpolószoba kifejezések készségesen értelmeződnek egy olyan módon, amelyen belül a gorpoló a gorpolás eseményére utal: 'segéd / kés / szoba a gorpoláshoz (amit a gorpolás során ilyen szerepben használnak)', miközben a Mikor lesz a gorpoló? megfogalmazás legalábbis erősen jelölt. A -hoz rag lekopására analógiát mutat a szélvédő esete (a széltól véd ez az alkatrésze a jármünek).
} 
esemény jelentésű eredményt nyújtó T-főnévképzésnek, mert nem geminált $t$-vel járó potenciális alakot adnak, mint mássalhangzó-kapcsolatra (6a'), sz-re (6b') vagy hosszú magánhangzóra (6c') végződő (hasonló jelentésű) társaik. Mindazonáltal úgy sejtjük, hogy még ennek a jelenségnek is lehet szemantikai aspektusa: a geminált $t$ preferáltan személy jelentésű T-főnevet sejtet, talán ebből adódik a (6) példasor erősen jelölt (szándékoltan esemény jelentésű) T-főneveinek ilyetén grammatikalitási státusza.

a. A tǔz eloltásával / elfojtásával / megfékezésével befejeződött a munkám.

a'. A tűz elolt*(??ot)tával / elfojt*(??ot)tával / (?)megfékeztével...5

b. A bor tegnapi megvevésével / megivásával / hazahozásával...

b'. A bor tegnapi ??megvettével / ??megittával / (?)hazahoztával...

c. A szőnyeg tegnapi megszövésével...

c'. A szőnyeg tegnapi ??megszőttével / *megszövöttével...

Az esemény jelentésű T-főnevek viszont a mondaton belüli szokásos grammatikai funkciók főnevekre jellemző eloszlása tekintetében viselkednek kirívóan „,őnévietlenül” (7): gyakorlatilag kizárólag időpontjelölésre alkalmas és használt események megnevezésében hajlandóak szerepet vállalni. Állítmányi (7a), alanyi (7b), tárgyi (7c), nem temporális oblikvuszi (7d") és névutós csoportbeli előfordulásaik elfogadhatatlanok, de még olyan időhatározóban sem szerepelhetnek, amelyik nem pontszerü időpontjelölést valósít meg (7f). Ez az erős korlátozás az adott típusú Tfőnévképzés bemenetére nézve is erős megszorítást állít fel: lényegében csak telikus eseményszerkezettel rendelkező igei szerkezetek jönnek szóba, mivel azok rendelkeznek (a nyelvbe is bekódolódott) kiemelkedő („salient”) időponttal. Ez az időpont a telikus struktúra esetében értelemszerüen a cél elérésének a pillanata; ezt a (7d-d') példapár kiválóan szemlélteti. Bármily szűk is az esemény jelentésű Tfőnevek derivációs bemeneti tartománya, fenntarthatjuk a hipotézist, hogy (archaikus mellékíze ellenére jelenleg még) produktív ez a képzés, hiszen ezen a tartományon elfogadható alakokat produkál.

(7) a. *Szerintem az izlandiak útja volt Amerika felfedezte.

b. *?Amerika felfedezte meglepte az embereket.

c. *?Megünnepelték Amerika felfedeztét.

d. ${ }^{(?)}$ Amerika felfedeztével új korszak kezdődött az emberiség életében.

d'. (?)Amerika felfedeztekor új korszak kezdődött az emberiség életében.

d". *?Nincs semmi meglepő Amerika felfedeztében.

e. *?Sokan érdeklődtek Amerika felfedezte iránt.

f. *?Sok minden történt Amerika felfedezte idején.

Ami a személy jelentésű T-főnevek morfológiai korlátait illeti, a (8) példasor alapján a legszembeötlőbb megfigyelésünk az lehet, hogy a megfeleltetett Ó-főnévi szerkezetek (8b, c, d, e) mindig kifogástalanok, míg a T-főnevek elfogadhatóságán sokféle tényező ronthat. A rövid bemeneti igealakok például kifejezetten nem preferáltak (8b', c', d'), szemben a hosszú (legalább két-három szótagos), és idegen eredetű és/vagy szokatlan hangtani felépítésű, hangulatfestő igealakokkal (8b', c', d'). Némi

${ }^{5} \mathrm{~A}\left(6 \mathrm{a}^{\prime}-\mathrm{c}^{\prime}\right)$ példákban is mindenütt az a mondatok befejezése, hogy „befejeződött a munkám”. 
preferenciát élveznek a (független fonotaktikai okok miatt) geminált $t$-vel képzendő alakok (8c', d', e'), sejtésünk szerint a fent már említett ok miatt: a személy jelentésü T-föneveket geminált $t$-vel várjuk. A kétféle T-főnév megkülönböztetésének igényét támasztja alá az a (8c')-ben bemutatott különös jelenség is, hogy a (múlt idejű igealakból előállítható) lelőttje potenciális derivátumnál egy számunkra érzékelhető árnyalattal elfogadhatóbb (bár még így is végső soron elfogadhatatlan, ahogy a táblázatban el is láttuk a '`?' ítélettel) a lelövöttje alak (ami nem állítható elő oly módon egy múlt idejü igealakból, mint a többi T-főnév). Megfogalmazható egy olyan hipotézis is, hogy elfogadhatóbbak a pozitív jelentéstartalmú T-főnevek $\left(8 e^{\prime}\right)$, de ennek kimondása komolyabb tesztelést igényelne.
a. Ki volt Ili tegnapi $[\ldots-$ ÓjA]?
a'. Ki volt Ili tegnapi [...-(Vt)tjA]?
b. ... megölője / meggyilkolója / likvidálója?
b'. ... *? megöltje / ?? meggyilkoltja / ?likvidáltja?
c. ... lelövője / lepuffantója / megfojtója?
c'. ... *lelőttje / *?lelövöttje / ?lepuffantottja / ?megfojtottja?
d. ... megverője/ eltángálója / megkínzója elagyabugyálója?
d'. ... *?megvertje / ??eltángáltja / ?megkínzottja / ?elagyabugyáltja?
e. ... megdicsérője / megcsókolója / felköszöntője / megmasszírozója?
e'. ... ??megdicsértje / ??megcsókoltja / ?felköszöntöttje / ?megmasszírozottja?

A személy jelentésű T-főnévképzés további természetességi feltétele egy olyan pragmatikai tényező, ami szintén jövőbeli kutatást igényel. A T-főnévvel való megnevezés sajátos alternatíváját jelenti a személyre való utalás olyan gyakoribb módjainak, mint a tulajdonnév, a foglalkozásnév, illetve a rokonsági vagy ismeretségi viszony felhasználása (Ilike / a fodrásznóm / a húgom vőlegénye). A (kifogástalanul elfogadható) Péter felfedezettje kifejezés például olyan kontextusokban győzheti le eme vetélytársait, amikor a megnevezett személynek ez a státusza valamiféle általa viselt „örök bélyegként” fogandó fel és éppen releváns. Ezek is olyan szigorú megszorítások, amelyek fényében nem meglepő az iménti példasorban látható sok jelölt alak.

Az alábbi táblázatban az iméntiekben kétszer is pedzegetett összefüggést szemléltetjük az esemény jelentésű T-főnevek és a személy jelentésű T-főnevek között, amelynek kiindulópontja az a morfofonológiai tényező, hogy a főnévképző is kétféle allomorfban ölthet testet, jelesül geminált és rövid -t-vel, valamint a birtokoltságjel is (-j-vel vagy anélkül), legalábbis 3 . személyben. Így két allomorfikus különbség is lehet egy esemény jelentésű T-főnév és személy jelentésű megfelelője között; az (a)-példák ilyen eseteket szemléltetnek. Nem-harmadik személyben azonban teljesen el is tűnhet a különbség, amennyiben például az ige - VI végződése kizárja a geminált - $t$ választását (d), vagy éppen a geminált $t$-s T-főnévképző válik kötelezővé - $-C C$ végződésű igék (d') esetében, illetve -ít végződésű igék (d") esetében (amelyek nyelvtörténeti okok miatt a releváns szempontból -CC végződésűnek számítanak; ld. Bárczi-Benkő-Berrár (1999: 105, 116)). 


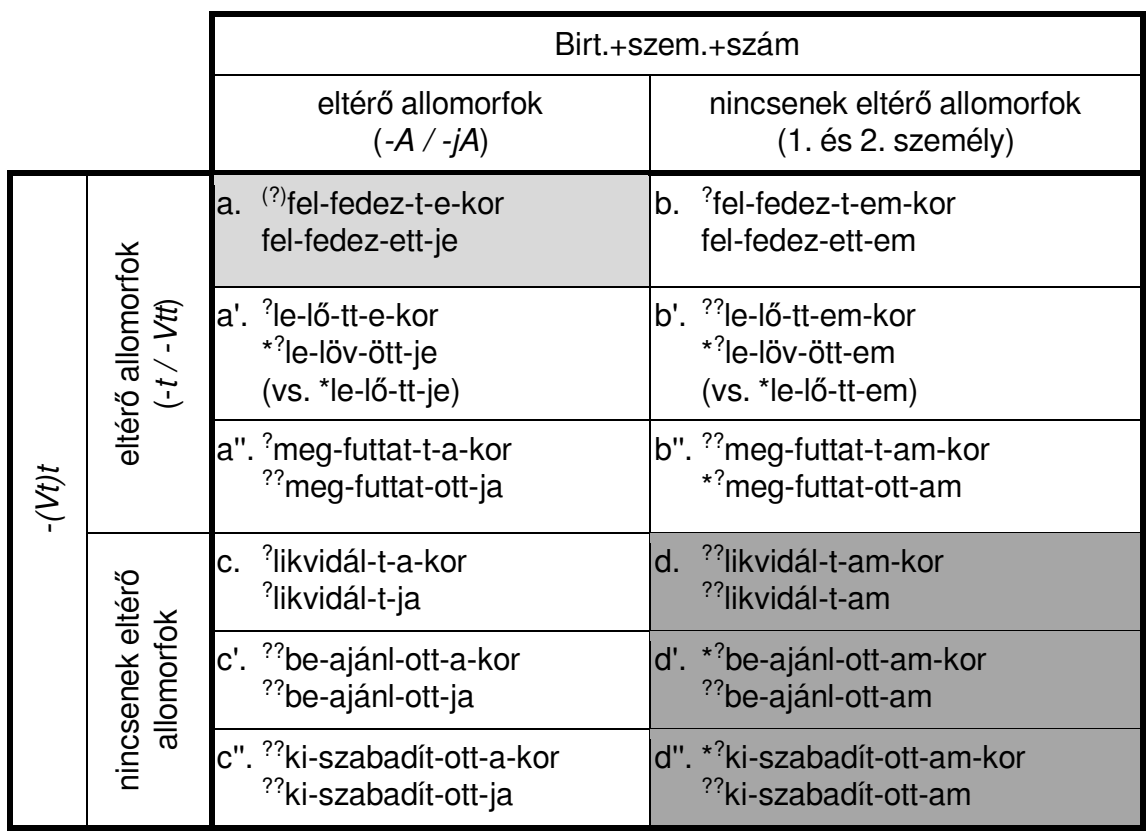

1. táblázat.

A két-két-féle -(Vt)t deverbális főnévképző és a birtokoltságjel társulása

A táblázat egy olyan plauzibilis hipotézist illusztrál, miszerint elfogadhatóbbak azok a személy/esemény jelentésű T-főnévi szerkezetek, amelyek több formai jegyben való eltéréssel különböztethetőek meg esemény/személy jelentésű párjuktól. ${ }^{6}$ Nyílván előnytelen az a teljes alaki egybeesés, amit a (9) példában bemutatott minimálpár szemléltet:

(9) a. ??Új szakaszába lépne az erőszakhullám a likvidál-t-am-mal.

b. ??Más sem bánt volna jobban a likvidál-t-am-mal.

Vegyük észre, hogy a tranzitív igei képzési bemenethez úgy viszonyul a kétféle Tfőnév, hogy az esemény jelentésű T-főnév esetében a birtokos a Téma lesz (vagyis engem készülnek likvidálni), míg a személy jelentésű T-főnév esetében az Ágens (én likvidáltam valakit). Ez a határozott intuíció újabb érv a kétféle T-főnévképzés produktivitása mellett, ami nyilván meg-megkérdőjeleződik az emberben a képzést

${ }^{6}$ Felmerülhet az olvasóban, hogy a nyelv nem mindig törekszik az eltérő formákra, például éppen a befejezett melléknévi igenév szisztematikusan egybeesik az ige múlt idejének $\mathrm{E} / 3$ alanyi ragozású változatával. A látott vagy elejtett szóalak például éppúgy lehet melléknévi igenév, mint múlt idejű ige. Van-e különbség e között az eset között és a kétféle T-főnév esete között? Nos, egy releváns különbséget említhetünk. A kétféle T-fönév szófajilag egybeesik, így a mondatbeli disztribúciójuk sem (feltétlenül) jelent támpontot az elkülönítésükre; míg ellenben a befejezett melléknévi igenév egész más mondatszerkezeti helyeken jelenhet meg, mint egy múlt idejü ige. 
gátló rengeteg tényező láttán. Egy másik összefüggés is feltűnhet azonban: ha a fonotaktikai körülmények megengedik, akkor úgy különbözteti meg a birtokoltságjel kétféle allomorfja a kétféle T-főnévképzést cselekvésleíró tranzitív igei bemenet esetén, hogy pontosan akkor jelenik meg a j-s változat, amikor a birtokos éppen Ágens. E megfigyelés jelentőségét a következő szakaszban fogjuk tüzetesen kifejteni; e szakaszban pedig azt tekintjük még át, hogy melyik T-főnévképzés esetében milyen tematikus szerepet szokott „örökölni” a birtokos más igei bemeneteknél.

Az alábbi (10) példasor (a-a') példái első pillantásra azt mutatják, hogy az esemény jelentésű T-főnévképzés csak akkor rendeli a bemeneti Témához a kimeneti birtokos szerepet, ha van a képzési bemeneten Téma argumentum (10b-c) - ennek híján azonban bemeneti Ágens is betöltheti a kimeneti birtokos szerepét, ahelyett, hogy rosszul formált potenciális T-főnévi szerkezetet kapnánk. Az esemény jelentésü T-főnevekről tehát inkább azt mondhatjuk ki, hogy alulspecifikálják birtokosuk tematikus szerepét (bár kétségtelen preferenciát biztosítva a Témának), mint azt, hogy kifejezetten ragaszkodnának a Témához.
a. ${ }^{(?)}$ Péter elköltöztével új korszak kezdődött az életünkben.
a'. (?)Péter megborotválkoztával befejeződtek a reggeli szertartásaink.
b. (?)Az ősz elérkeztével rosszabbra fordult az idő.
c. (?)A könyv megírtával új korszak kezdődött az életünkben.
d. 'Péter átköltöztével Budáról Pestre könnyebb lett a kapcsolattartás.
e. A gyerekeknek az újságpapírból való (?)montázscsinálásával /
*montázscsináltával befejeződött a munka.

A tematikus szerepek kínálta elemzésnél finomabb vonzatszemantikai elemzés azonban - például ha Dowtyt (1991) követve górcső alá vesszük az ágentivitás összetevőit - megmutatja, hogy prototipikus Ágens nem kaphatja meg a birtokosi funkciót egy esemény jelentésű T-főnév mellett (10e). Hiába próbáljuk ugyanis (egy korábban említett kritérium miatt) telikusan értelmezni a (10e) T-főnévi szerkezete mögött álló igei konstrukciót („a gyerekek montázst csináltak az újságpapírból”), az adott szerkezet nem ad elfogadható mondatot. Ami az ágentivitás fokozatait illeti, a (10e) összevetése a (10a, a', d) példákkal azt mutatja, hogy az esemény jelentésű T-főnév olyan „gyenge Ágenst” még elfogad birtokosként, amelyikről - megnevezett behatott szereplő híján - tulajdonképpen azt állítjuk, hogy önmagára hat a cselekvésével (10a, a', d), de olyan ,igazi Ágenst” már nem, amelyik egy megnevezett másik szereplőre fejti ki hatását (jelesül a készülő montázsra a (10e) példában).

Az alábbi (11) példasorban a személy jelentésű T-főnevek birtokosának tematikus szerepét vesszük górcső alá. Csak az Ágens szerep válik be, a (11c, d, d', e) példák tanúsága szerint (NB: a (11d-e) T-főnévi szerkezeteit a T-főnév komplementumzónájában hagyott másik vonzat teszi - beszélőtől függően többé vagy kevésbé - jelöltté). A képzési bemeneten meglévő Téma a kimeneten maga a denotátum lesz a T-főnévi konstrukció esetében. Ezt a (11c-e) példák világosan mutatják, de a (11a) és a (11b) közötti grammatikalitási különbség is ezt erősíti meg. Ami ez utóbbi (11a) és (11b) példákban közös, az az, hogy a bemeneti igének egyetlen vonzata van, amiből denotátum lesz a kimeneten, így a birtokosnak nem jut igei jellegű tematikus szerep, csupán valamiféle (a nem képzett főnevekhez is társítható) fogalmi szerep (Laczkó 2000: 293-303). Ami pedig e két példában eltér, 
az a bemeneti vonzat tematikus szerepe: a (11a) potenciális T-főnév egy Ágenst jelölne, ami kizárt, míg a (11b) T-főneve egy Témát, ami „kevésbé kizárt”. Feltehetőleg itt a tematikus szerepet viselő birtokos hiánya okozza az erős jelöltséget.

a. *A tanszék tegnapi teniszezettjeire jogosan lehetünk büszkék.

b. ??A tanszék tegnapi megbetegedettjei már jól vannak.

c. Találkoztál Péter tavalyi felfedezettjével / megbízottjával / protezsáltjával / 'kitartottjával / 'támogatottjával / 'kezeltjével?

d. ?Nem vált be Péter tavalyi beprotezsáltja a bizottságba.

d'. ?Péter tavalyi meghívottja a partira emlékeim szerint nagyon berúgott.

e. 'Elpusztultak a cár tavalyi Szibériába számüzöttjei.

Mindent egybevetve tehát az esemény jelentésű T-főnév nem fogad el prototikus Ágenst birtokosának, míg a személy jelentésű T-főnév kifejezetten prototipikus („Téma mellől érkező”) ágensi szerepet követel meg a birtokosa számára. Mint láttuk, a birtokoltságjel morfémáján belül éppen ez utóbbi esetben jelenik meg az elidegeníthető viszonnyal összefüggésbe hozott -j- elem (den Dikken 2015). Ez pedig szépen összecseng azzal az uralkodó nézettel (Id. pl. (Marantz 1984), (Kratzer 1996)), miszerint az Ágens viszonya a régensével „külsődleges” az inherens(ebb) Téma-régens viszonyhoz képest - mindkét hipotézist megerősítve ezzel, amennyiben a „külsődlegességet” és az elidegeníthetőséget ugyanazon érem két oldalának tekintjük.

\section{Félúton davidsoniánusok és neo-davidsoniánusok között}

Az imént említett aszimmetria az ige „inherens” Témája és „külsődleges” Ágense között még nem merül fel annak a Davidsonnak (1967) az elméletében, akinek az eseményre utaló, azaz eventuális szereplő fogalmának a bevezetését köszönhetjük.

Az alábbi (12a) logikai reprezentáció szemlélteti a fenti gondolatot, mely a (12a') mondat jelentését hivatott (nyilván a céljainkat nem befolyásoló egyszerüsítés mellett) megragadni. Így önthetjük szavakba a logikai formula tartalmát: a mondat egy olyan esemény létezését állítja, amely Jani és egy pirítós között „zajlik le” vajazás formájában, amely lassan megy végbe, éjfélkor, a fürdőszobában, egy kés segítségével.

\footnotetext{
a. ᄏe[VAJAZÁS(e,Jani,egy_pirítós) \& LASSÚ(e) \& IDEJE(e,éjfél) \& $\operatorname{BENN}$ (e,a_fürdőszoba) \& ESZKÖZE(e,egy_kés)]

a'. Jani lassan megvajazott egy pirítóst éjfélkor a fürdőszobában egy késsel.

b. ヨe[VAJAZÁS(e) \& ÁGENSE(e,Jani) \& TÉMÁJA(e,egy_pirítós)]

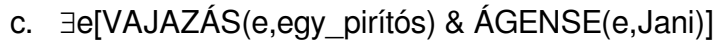

Parsons (1990) neo-davidsoniánusnak nevezett követői nemcsak a szabad határozókat különítik el a mondat tartalmát kifejező reprezentációban a közölt esemény magvától, hanem a vonzatokat is, ahogyan azt a fenti (12b) formula mutatja. Ez a formula azt mondja tehát, hogy egy vajazási esemény történik, amelyet Jani hajt 
végre, és amelynek révén egy pirítós szenved el változást. Az Ágens és a Téma szerepe amúgy ebben a felfogásban is szimmetrikus.

Az aszimmerikus felfogást (12c) - miszerint az igének az eventuális argumentumán kívül egy Téma argumentuma van, az Ágenst pedig egy önálló predikátum hozza kapcsolatba az eventualitással - például Kratzer (1996) képviseli, többek között Marantz (1984) következő érvére támaszkodva: egy ige pontos jelentése az után dől el, hogy társult a Téma argumentumával (míg az ige+Ágens párosnak szinte soha nincs ilyen hatása). Olyan jellegű igékkel is példálóznak az aszimmetrikus felfogás képviselői, mint amilyen mondjuk a magyarban a fagyaszt ige: az -Aszt képző úgy fogható fel, mint ha a (12c) képletben az ÁGENS predikátum megtestesülése lenne, OKOZZA jelentéstartalommal: olyan eseményt okoz tehát valaki, miszerint megfagy valami. Az aszimmetrikus felfogás melletti további érvekről az érdeklődő olvasó például Lohndal (2012) cikkéből tájékozódhat, amelyben az ellenérvek is helyet kaptak.

Ebben az aszimmetrikus keretben a (13) példában bemutatott módon adhatunk számot a 2. szakaszban tárgyalt problémára.

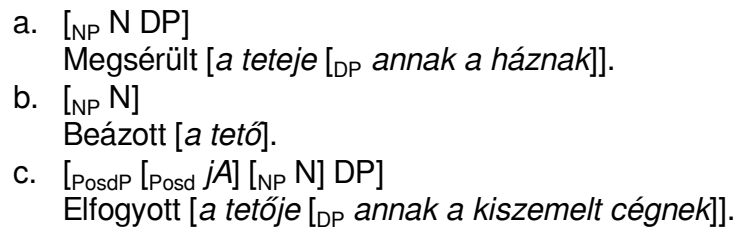

A birtokszó elidegeníthetetlen birtokának argumentumhelyével együtt (13a), illetve anélkül is (13b) el van tárolva a lexikonban, hiszen nem jósolható meg e két hangalak. Az elidegeníthető birtokost viszont egy külön operátor társítja az imént említett birtokos nélküli tőhöz (13b), amely a -jA toldalékot illeszti hozzá, így kapjuk meg a (2. szakaszban definiált) potenciális reguláris birtokszóváltozatot (13c). ${ }^{7}$ Ez a cárja birtokszóváltozat esetében, amely a további példákkal egyetemben az (1) példasorban szerepelt, egybeesik a (13a) típusú lexikalizált birtokszóváltozattal. Más esetekben - esetleg csak egyes anyanyelvi beszélők - a (13c)-nek megfelelő változatot a (13a)-nak megfelelő változatból konverzióval hozzák létre, elveszítve egy szemantikai oppozíció kifejezését; a has főnév esetében ennek kikerülhetetlen fonotaktikai oka van, a fôtér szó esetében viszont nem világos az ok.

A (13c) pontban bemutatott Posd operátor tehát kétféle morfofonológiai változás előidézése révén mutatkozik meg, amelyek versengenek egymással a

\footnotetext{
7 Megjegyzendő, hogy ez a gondolatmenet lényegében egybevág Laczkó (2009) gondolatmenetével. Ehelyütt jegyezzük meg azt is, hogy e cikkben egy régens vonzatát a javasolt szintaktikai szerkezetekben általában a régensnek megfelelő fej komplementumzónájában vesszük fel (azaz a fej mögött, lényegében), és nem a specifikálójában (NB: e komplementumzóna több argumentumhelyet is tartalmazhat, például a (13c) szerkezetben kettőt, összhangban azzal, hogy a Posd fejbeli -jA elemnek éppen az a feladata, hogy egy tetszőleges főnévi kifejezést „elidegeníthetően birtokolttá” tegyen egy másik főnévi kifejezés hozzátársítása révén). E gyakorlat elméletfüggő vonatkozásaival jelenleg nem kívánunk foglalkozni, mert az túlnőne e cikk keretein. A kérdésben elkötelezett szintakta olvasót arra kérjük, hogy állításaink tartalmi részét vegye figyelembe.
} 
grammatikában, alapvetően fonotaktikai tényezők befolyása szerint felülkerekedve egymáson, de jelentékeny beszélőfüggő különbségeket is okozva.

A 3. szakasz (4) példasorában áttekintett termékeny magyar főnévképzések működését az alábbi (14b-e') példasorban bemutatott (értelemszerűen egyszerüsített) szerkezetek ragadják meg, legalábbis a (12c) reprezentáció finomságának a szintjén, kiindulva az azzal egyenértékű (14a) reprezentációból. ${ }^{8}$ Ez utóbbi tehát azt fejezi ki, hogy a tranzitív ige először Témájával társul VP igei csoporttá, majd egy v szintaktikai fejben lévő okozást (ágensi hozzájárulást) kifejező operátor veszi komplementumzónájába ezt a VP-t egy olyan szereplővel társítva, amelynek ágensi karaktere abból adódik, hogy az operátor azt állítja róla, hogy ő okozza a VP-ben leírt esemény bekövetkezését.

a. [AspP $\left.f_{\text {AdvP }}\left[{ }_{\mathrm{vp}} \vee \mathrm{DP}_{\mathrm{Ag}}\left[\mathrm{vP} \vee \mathrm{DP}_{\mathrm{Th}}\right]\right]\right]$

Péter felfedezte Dórit.

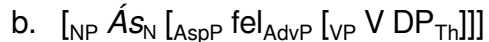
Dóri felfedezésének nagyon örültem.

b'. [NP $\left.A s_{\mathrm{N}}\left[{ }_{\mathrm{AspP}} \mathrm{XP}_{\mathrm{Th}}\left[\mathrm{vP} \vee \mathrm{DP}_{\mathrm{Ag}}[\mathrm{vp} \mathrm{V}]\right]\right]\right]$ A gyerekek montázscsinálásával...

b". [NP $A s^{*}{ }_{N}\left[{ }_{v P}\right.$ fel $\left.\left._{\text {AdvP }} \mathrm{V}\right]\right]$ $A$ jelentős felfedezések örömöt okoznak.

b"'. [PosdP Posd DP [NP Ás ${ }_{N}^{*}$ [vP fel $_{\text {AdvP V] }}$ Turing felfedezésének köszönhették az angolok a háború megnyerését.

c. [NP $T_{\mathrm{N}}\left[\right.$ AspP $\left.\left.\left._{\text {fel }} \mathrm{fdvP}_{\mathrm{AdvP}} \mathrm{V} \mathrm{DP}_{\mathrm{Th}}\right]\right]\right]$ Dóri felfedeztéve/ Péter élete is megújult.

c'. [NP $T_{\mathrm{N}}\left[\right.$ AspP $_{\text {fel }}$ fdvP $\left.\left.\left._{\text {ivP }} \vee \mathrm{DP}_{\mathrm{Ag}}\left[\mathrm{vP} \vee \underline{\mathrm{DP}}_{\mathrm{Th}}\right]\right]\right]\right]$ Dóri Péter felfedezettje.

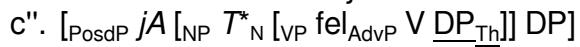
Dóri az év felfedezettje.

d. ${ }_{\mathrm{NP}} O_{\mathrm{N}}\left[{ }_{\mathrm{AspP}}\right.$ be $\left.\left._{\mathrm{AdvP}}\left[\mathrm{vP} \vee \mathrm{DP}_{\mathrm{Ag}}\left[\mathrm{vP} \vee \mathrm{DP} \mathrm{P}_{\mathrm{Th}}\right]\right]\right]\right]$ Péter a hír elsó bemondója.

d'. [PosdP $\left.j A\left[_{\mathrm{NP}} O^{\star}{ }_{\mathrm{N}}\left[\mathrm{vP} \vee \underline{\mathrm{DP}}_{\mathrm{Ag}}\left[\mathrm{vP} \mathrm{be}_{\mathrm{AdvP}} \mathrm{V}\right]\right]\right] \mathrm{DP}\right]$ Ili az M99 bemondója.

e. [NP $H N_{N}\left[\right.$ AspP [vP $v$ DP ${ }_{\text {Ag }}[\mathrm{vP}$ V]]]] Ili leküzdhetetlen dolgozhatnékja

e'. [NP $\left.H N_{\mathrm{N}}\left[\mathrm{AspP}\left[\mathrm{vP} \vee \mathrm{DP}_{\mathrm{i}}\left[\mathrm{vP} \vee \mathrm{DP} \mathrm{P}_{\mathrm{i}}\right]\right]\right]\right]$ Ili leküzdhetetlen tüsszöghetnékje

Az -Ás (14b) alapesetben a VP egységet veszi komplementumzónájába, nem a nagyobb vP-t, mivel az Ágens nincs jelen a szintaktikailag megjelenítendő elemek között (amit a képző elvárásának tulajdoníthatunk). A kifejezendő Téma pedig összhangban a $\mathrm{V} \rightarrow \mathrm{N}$ kategóriaváltással - birtokosként veendő fel. $\mathrm{A} \mathrm{DP} \mathrm{Th}_{\mathrm{Th}}$ csoport tehát hangalakot nem a (14a) képletben látható helyen, hanem az NP csomópont feletti szerkezetben fog ölteni.

8 Javaslataink abban a szellemben fogantak, amelynek egy korai megnyilvánulása például (Fu-Roeper-Borer 2001) cikke, egy kurrens írás pedig Dékányé (2014). Az alapötlet: egy igéből képzett fönévi kifejezés szerkezete úgy fest, hogy az alsó szintaktikai héjak az igei szerkezetekre jellemzőek, a felsőbbek pedig a főnévi szerkezetekre. 
Az -Ás-képzés általános és részletekbe menő tárgyalása túlnő e cikk keretein. Azt azonban megemlítjük, hogy ez az -Ás főnévképzőnek az a változata, amelyik komplex esemény jelentésű főnévi konstrukciót képez (Laczkó 2000) rendszerének besorolása szerint. A komplex esemény jelentésü deverbális nominális szerkezetekben, ellentétben az egyszerü esemény jelentésű szerkezetekkel, a főnévképző egy AspP aspektuális projekciót (Alberti-Medve 2002/2005) (vagy egy PredP predikatív projekciót (É. Kiss 2006; 2008)) vesz a komplementumzónájába, mert így adhatunk számot a komplexesemény-jelentés bizonyos vonatkozásairól.

A (14b') típus esetében az -Ás képző egy vP-t tartozó AspP-t vesz a komplementumzónájába (ld. (10e)), hiszen ez esetben az Ágens a birtokos. Az $\mathrm{XP}_{\mathrm{Th}}$ jelöléssel arra utalunk, hogy a montázs hangalak mögött nem teljes DP áll, hanem részleges (kiépültségü) főnévi kifejezés.

A (14b") példában bemutatjuk a Laczkó (2000) által egyszerű esemény jelentésű főnévi konstrukciót képező -Ás képzőt is (amit fent Ás* jelöl; az eseménytípusok magyarázatát az idézett cikkben találhatja meg az olvasó): ez a képző úgy veszi komplementumzónájába a VP-t, hogy még a Téma szereplőt is „leköti egzisztenciálisan", azaz szintaktikailag ki nem fejezendővé teszi. Ezen azt értjük, hogy a szintaktikai generálás során egyáltalán nem jelenik meg ez a pozíció, ami a bemeneti igéhez képest tekintendő szemantikai módosulásnak köszönhetően majd nem is hiányzik. ${ }^{9}$

Térjünk rá a (14b"') birtokos szerkezet tárgyalására! Analógiát láthatunk a (13) példasorral: a Posd operátor a (14b") konstrukcióhoz birtokost társíthat, szabad szemantikai tartalommal; a szabadságba belefér, hogy történetesen éppen az Ágenst válasszuk birtokosnak, mint a (14b"') példában, de az is lehetséges, hogy egy időhatározó töltse be a birtokosi szerepet, mint az évszázad felfedezése szerkezetben (nem abban az értelemben tekintve, hogy az évszázadot fedezi fel valaki Témaként, hanem abban az értelemben, hogy 'a legnagyobb felfedezés az évszázadban'). A jelentés-hozzárendelés kérdésére majd visszatérünk a (15) példasor kapcsán. Az a döntő mozzanat az egyszerű esemény jelentésű főnévi kifejezéseket létrehozó -Ás képzésnél, hogy az (amúgy nem is kötelezően kitöltendő) birtokosi szerepbe nem egy szintaktikailag előre kijelölt szereplő lép be, hanem egy olyan szereplő, amelynek kapcsolatát a birtokszóval (saját szemantikai tartalmából kiindulva) egy gazdag konceptuális jelentéshálózat alapján számíthatjuk ki (amelyben természetesen az eredeti igei szerepekhez is eljuthatunk). A Turing kedvenc felfedezése birtokos szerkezet például már egyenesen kétértelmü: a kontextus fogja eldönteni, hogy Turing Ágensként értelmezendő, vagy olyan személyként, aki mások felfedezései közül választ kedvencet (NB: amennyiben úgy értjük a (14b"') mondatot, hogy Turingot fedezik fel (Témaként), akkor a (14b) szerkezetet kapjuk vissza).

Az esemény jelentésű főnévi konstrukciót létrehozó T-képzés (14c) lényegében ugyanúgy írható le, mint az -Ás-képzés (14b-b'), csak az értelmezési tartomány

${ }^{9}$ A szintaxis olyan VP-struktúrát generál, ami amúgy mondjuk a hajnalodik ige behelyettesítését engedné meg. Az Ás képző szemantikai hatása azonban éppen olyan, hogy egy ige megfelelő projekcióját gyakorlatilag az Ágenstől és a Témától (és esetleg a további szereplőktől is) megfosztva fogadja el. Míg sok nyelvben egy passzív képző feladata, hogy lehetővé tegye az Ágens (és a Téma) ki nem fejezését ( ${ }^{*} L o p v a$ volt), a magyarban az Ás* képző kínál megfelelő formát ( ${ }^{*}$ Lopás történt). 
más (sokkal szűkebb). A (10) példasor tanulságai alapján azt állítjuk, hogy a „nem prototipikus Ágens”, amiből a birtokos lesz, mindenképpen argumentumhelyet kap a VP-ben (NB: így adhatunk számot a (10e) példában megadott alapjában véve elfogadható ÁS-főnévi konstrukció és az elfogadhatatlan T-főnévi konstrukció e radikális grammatikalitási különbségéről). Ez a megírt könyv esetében (10c) nem szorul magyarázatra, viszont például az el-/átköltöző vagy borotválkozó szereplő esetében (10a-a') igen. Ez utóbbi esetekben az a javaslatunk, hogy az ominózus szereplő képviseltessék a VP-ben és a külső vP-héjban egyaránt egy-egy kópiája révén, így kifejezve, hogy cselekvésének behatottja ő maga. ${ }^{10}$

A (14c) képzés komplex esemény jelentésű főnévi kifejezést hoz létre, ebből következően kötelezően megjelenítendő Téma jellegű argumentummal, ami birtokosként fejezendő ki. Azt állítjuk, hogy egyszerü esemény jelentésű párja nincsen ennek az eventuális T-képzőnek, így hát az eventuális T-képző mindig birtokos szerkezetet épít maga köré. Ezért nem jól formált a felfedeztekor alakhoz képest előállítható felfedezet alak (felfedezés értelemben); csak néhány olyan lexikalizálódott kövület őrzi e képzés (korábban valamilyen igenévi formában meg is valósuló) lehetőségét, mint szeretet, tisztelet, gyülölet, utálat, jövet-menet (ld. Dékány 2014).

A személy jelentésű T-főnév (14c') szerkezetében a főnévképző nyilván egy vP projekciót tartalmazó AspP-t ${ }^{11}$ vesz komplementumzónájába, hiszen - mint a (11) példasor kapcsán rámutattunk - a birtokos az Ágensből lesz. A szerkezeti képletben a Téma DP-jének aláhúzott volta azt jelzi, hogy predikatív helyzetben az lesz a mondat alanya, egyébként pedig a T-főnévi szerkezet denotátuma (ez utóbbi esetben az aláhúzott argumentumhely nem épül ki a szintaxisban, az „i-ben i” tiltása elvének értelmében).

Érdemes elöreugrani a (14d) szerkezethez, amely annyiban különbözik csak a (14c') szerkezettől, hogy az Ágens DP-je van aláhúzva, ugyanilyen okból: ha az

${ }^{10} \mathrm{E}$ felvetés szerint tehát a telikus unergatív igei konstrukciók nem prototipikus unergatív konstrukciók, mert azoknak nincsen VP-beli „,behatott” szereplőjük, csak vP-héjbeli Ágensük. Vegyük észre, hogy az már elfogadhatatlan, hogy *Péter énekeltével befejeződött a munkánk (az atelikus énekel itt a prototipikus unergatív ige). A telicitás egy cél elérését jelenti, amit tárgy / Téma híján az Ágensen mérünk le (például borostamentes-e az arca, illetve új helyen lakik-e).

${ }^{11}$ Bár a (14c') és (14d) példákban szereplő főnévi kifejezések személyre utalnak, a képzés alapjául komplex esemény szolgál; aminek a szintaktikai vetülete az, hogy „legalább” egy AspP projekció kiépülését kell feltételeznünk a főnévképző komplementumzónájában. A személyre való utalás ugyanis - Laczkó (2000: 379) kifejezésével éve - eseti módon történik e két példában (ellentétben a (14c") és (14d') példákkal), és „az 'eseti' cselekvőt kifejező Ófőnevek megőrzik az eredeti ige argumentumszerkezetét" (amin esetünkben egyfajta komplex eseményszerkezetet is kell értenünk). Tekintsük át a referenciális változatokat, hogy világosan elváljon az AspP-hez kapcsolódó komplex esemény magától a referenciától - az AspP kifejezésen belül ugyanis három szereplő van jelen: a felfedező személy (Ágens), a felfedezett személy (Téma) és a felfedezés eseménye mint absztrakt szereplő maga (Davidson 1967; Parsons 1990)! A (14a) mondatban az ige finitsége azt vonja maga után, hogy a mondat egészét referenciálisan az eventuális, azaz Davidson-féle absztrakt referensre vonatkoztassuk, és ugyanezt a referenciális hatást váltja ki a $(14 b, c)$ példákban szemléltetett két főnévképző is (az -Ás és a - $(V t) t(A))$ a képzett főnévi kifejezés egészére vonatkozóan; míg a (14c') és a (14d) példákban a másik két főnévképző $(a z-(V t) t(j A)$ és az -Ó) referenciálisan a Téma, illetve az Ágens szereplőre való utalást írja elő, oly módon azonosítva őket, hogy részesei az adott komplex eseménynek. 
Ó-főnévi szerkezet predikatív helyzetben áll, akkor az Ágens az alanyi szerepet kapja, egyébként pedig a denotátumi szerepet. A Téma és Ágens közötti szerepcsere azt nem befolyásolja, hogy az Ó-főnév képzője is a vP-t veszi komplementumzónájába.

A személyt jelölő T-főnévképzőnek is van olyan változata (v.ö. (14b")), amely egyszerű esemény alapján meghatározott szereplőt jelöl (14c"); ezt a T*-konstrukciót pedig szabadon választott jelentéshozadékú birtokos egészítheti ki. Érdemes ezen a ponton felfigyelni a (14c/c") és a (13a/c) közötti analógiára: a (14c") típusban éppúgy potenciális reguláris birtokszóváltozat képzését látjuk, mint a (13c) típusban, ezért más a birtokszóváltozat ebben a két esetben, mint azokban az esetekben - a (13a) és a (14c) típusra gondolunk -, amikor egy belső argumentum kapja meg a birtokosi szerepet. ${ }^{12}$

A (14d') szerkezet a (14d) szerkezettel vetendő össze. A demonstrált Ó*-főnévképzés újra egy egyszerű esemény alapján meghatározott szereplőt jelöl (a bemeneti Téma elnyomásával), amelyhez ismét társíthatunk „szabad birtokost”, amit ismét potenciális reguláris birtokszóváltozat jelez, mint azt a -jA toldalék mutatja. Az igazsághoz persze hozzátartozik, hogy a magánhangzóra végződő képzett főnév másfajta birtokszóváltozatot nem is igazán nyerhetne.

Végül a (14e-e') szerkezetek kétféle bemenetű HATNÉK-konstrukciót ragadnak meg. A (14e) változatban a birtokos prototipikus Ágens, ezért a (14c') szerkezet áll közel hozzá. A (14e') változat esetében a bemeneti ige egyetlen vonzata olyan szerepet játszik, amelynek betöltője részlegesen kontrollálja önmagát, így feltételezhetjük, hogy egyszerre Ágens és Téma. Figyeljük meg, hogy a főnévi fej a potenciális reguláris birtokszóváltozatát ölti fel, akárcsak a többi esetben, amikor a főnévképző nem VP-t, hanem vP-t vesz komplementumzónájába - tehát ez a változat a „külső héj” megjelenésének tulajdonítható. Az, hogy a -hAtnék-ra végződő képzett elemek -jA toldalékot kapnak, motivált jelenség, mivel az ajándékja vagy verejtékje potenciális reguláris birtokszóváltozatok kizárólag olyan elidegeníthető birtokviszonyok kifejezésében jelenhetnek meg (legalábbis egyes beszélőknél), mint „az utóbbi idők [legötletesebb ajándékja] / [legbőségesebb verejtékje]” (amúgy az ajándéka és verejtéke birtokszóváltozatok a természetesek).

Ellenőrizhetjük: valamennyi produktív fönévképző betartja a 2. szakaszban bemutatott (2) szabályt, sőt még a sokkal szigorúbb (3a-b) szabályt is; gyakorlatilag persze a kétféle T-képzőről és a HATNÉK-képzőről van szó: a fonotaktikailag ki nem kényszerített -jA toldalékalak ágensi, tehát „külsőleg felvett” birtokost jelez (a szakasz elején tárgyalt Kratzer-féle (1996) aszimmetrikus felfogás értelmében).

Térjünk most vissza a birtokos eltérő szerepeinek szemantikai problémájára, amit még a (14b'") típus kommentálása során érintettünk. Hogy lehet az, hogy ugyanazon igei tő mellett az alany és a tárgy annyiféle szerepet ölthet?! A főnév mellett pedig a birtokossal történik meg ugyanez?! A probléma ugyanaz, amit az ás ige családján szoktunk szemléltetni argumentumszerkezet-felfogásunk fejlődő változatainak bemutatása során (ld. legutóbb Farkas (2015), korábban pl. Alberti (Alberti 2006; 2009; 2013)). A (15) példasor annyit idéz fel az említett jelenségből,

\footnotetext{
12 Vegyük észre, hogy a (14c) szerkezetben nincsen aláhúzással megjelölt szereplő; éppen ez a hiány kódolja azt a körülményt, hogy a főnévi szerkezet jelölete egy eventualitás, és nem a bemeneti igei konstrukció Ágense vagy Témája.
} 
hogy az ás igető mellett felbukkanhat alanyként és tárgyként az ásás végzője (mint Ágens) és a megmunkált föld (mint Téma), ahogyan azt a (15a) szemlélteti, de akár mindkét szereplő (kifejtése) hiányozhat (15b), vagy éppen más szereplők ragadják magukhoz az alanyi és a tárgyi szerepet: jelesül az Ágens „munkáltatója” és a föld megmunkálása során előállított gödörben elhelyezett kincs (15c).
a. [vp v DP [vp V DP]]
Kínlódva [vP ásták [DP ók] [DP a fagyos földef]].
b. [NP Ás ${ }_{\mathrm{N}}^{*}[\mathrm{vP}$ V]]
Fáradságos tevékenység [az ásás].
c. [vp $\mathrm{Cau}^{(t) A t}{ }_{v} \mathrm{DP}\left[{ }_{\mathrm{vP}} \mathrm{Cau}_{\mathrm{v}}^{e l}\left[{ }_{\mathrm{vP}} \mathrm{Cau}_{\mathrm{v}}\left[{ }_{\mathrm{vP}} \mathrm{Cau}_{\mathrm{v}}\left[{ }_{\mathrm{vP}} \mathrm{V}\right]\right]\right]\right.$ DP]]
Elásatta [DP a vezér [DP a kincsekef]].
d. Vendel egész szép villát ásott össze magának.

A fentiekben már említett Lohndal (2012) hasonló argumentumszerkezet-családi burjánzások áttekintését követően jut el oda, hogy egyszerüen értelmetlen a kérdés egy adott ige esetében: „hány vonzata van?”, vagy „milyen a vonzatszerkezete?”, és levonja a következtetést, hogy a lexikai szemantika és a szintaxis között nem az a triviális kapcsolat áll fenn, amit gyakran feltételezünk. Vagyis nem abban áll ez a kapcsolat, hogy „érkezik a régens a maga vonzatszerkezeti igényével”, és belép egy ezt éppen kielégítő szintaktikai szerkezetbe. Az argumentumstruktúrák kora lejárt! - hirdeti Lohndal (2012) cikkének címében.

Lazább kapcsolatot, gazdagabb szemantikát, a szintaxis számára szabadabb megnyilvánulást feltételez - amit argumentumszerkezet-elméletünkkel (Alberti 2006; 2009; 2013; Farkas 2015) a következő módon integrálhatunk.

Egyfelöl a szemantika oldaláról potenciális szereplők egy gazdag és jól strukturált hálózata jelenik meg, középpontjában az ásással kapcsolatos minden (nem metaforikus) argumentumstruktúra-változat közös jelentéselemével: valaki ('Ág', azaz az Ágens) ássa a földet (a 'Pác', azaz Páciens megnevezés az e cikkben Témának titulált szereplöre utal). E cselekvés nyomán például gödör jöhet létre ('Kp', azaz Kezdőpont ${ }^{13}$ ), a sikeres gödörásás következtében pedig lehetővé válik egy kincs ('Pác"') „állapotának” olyan befolyásolása, hogy elrejtetté váljon. Mindez pedig egy Okozó ('Ok') parancsára létrejött helyzet is lehet. Az alábbi ábra gazdagabb mentális hálózatot mutat be (amelyben az ásás például egy kert egészének megmüvelésére - felásására - is irányulhat), de jelen céljainkra most elegendő ennek az egy hatásláncolatnak a bemutatása: az Okozó tehát „odahat”, hogy az Ágens ásás révén módosítsa a Téma, azaz a föld állapotát, aminek révén gödör jöhet létre (NB: a gödörből mint Kezdőpontból távozik a föld), és ez lehetővé teszi a kincs elásás révén történő állapotmódosítását.

\footnotetext{
${ }^{13} \mathrm{~A}$ bekezdés végén érvelünk a mellett, hogy miért éppen Kezdőpont, és nem például Végpont tematikus címkével látjuk el a gödröt. Annyit érdemes még hozzátenni, hogy a sírt főnévi szerkezetet címkéznénk meg Végpontként az 1. ábrán a megásta a sirt konstrukcióban az alapján, hogy „sírnak ássák a gödröt”.
} 


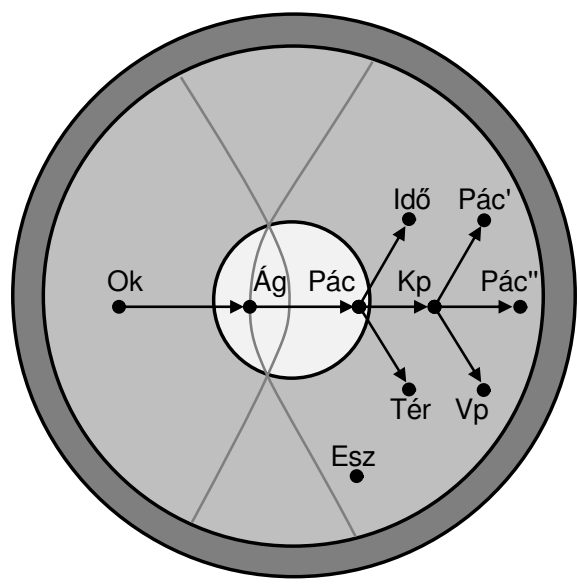

1. ábra.

Az ás igéhez kapcsolódó egyszerüsített szerephálózat

A szintaxis - némi egyszerűsítéssel szólva - betöltendő DP-helyeket hoz létre, eredendően függetlenül működve a maga szabályai szerint. Az üzenet címzettje felől nézve a szintaxis és szemantika közötti illesztés feladatát, a címzett dönthet úgy az igemorfológia (jelen esetben képzők jelen nem léte) és a DP-kre vonatkozó jelentésbeli korlátok (azaz a szemantikai szelekció) felmérése alapján, hogy a magjelentéssel áll szemben. A (15a) mondat hallatán például ez reális döntés. Két DP-hely van felkínálva, amelyek betöltésére a szemantikai hálózatból az Ágens és a Téma ('Pác') messzemenőkig alkalmas. A (15b) mondat nem hív meg egyetlen szereplőt sem a jelentéshálózatból. A nyelv erre is lehetőséget biztosít, jellemzően nominális eszközökkel, például az -Ás* képző segítségével (míg az ige mellett általában elkerülhetetlen legalább egy argumentumnak a kifejtése). Maga az ásási jelentéshálózat lett tehát meghívva (15b) révén - amit „logikai lekötéssel” értelmezhet a címzett, valahogy így: ha valaki ás valamit, akkor elfárad.

A (15c) mondat hallatán a két DP tartalma és az igemorfológia segít e két DP jelentéshálózatbeli szerepének azonosításában. A tárgy behatott szereplő, de a kincs nem olyan anyag, amit értelmes lenne ásással mondjuk porhanyóssá tenni. Más behatott szereplőt érdemes tehát keresni a jelentéshálózatban fellelhető hatásláncolatban (a magjelentéstől elindulva), okozási (a fenti képletben 'Cau') relációt kipróbálva, aminek az igemorfológiában konverzió is lehet a megnyilvánulása, ahogyan az ás egy gödröt példa mutatja. A kincs azonban nem olyan típusú szereplö, mint a gödör, érdemes tehát még egy okozási lépést tenni, amit az el igekötő végső soron képzői funkcióban - jelöl is (ld. 'Cau $\left.{ }^{e /}\right)$ : a tárgyi DP számára így megtalálhatjuk a Pác" szereplőt („,amit ásás révén elrejthetünk egy gödörben”). A müveltetés képzője pedig újabb kauzatív relációt hív meg (Id. 'Cau $\left.{ }^{(t) A t^{\prime}}\right)$. Megjegyzendő, hogy mindhárom kauzatív operáció azon az áron hív meg új szereplőt a reprezentációba, hogy egy másikat „egzisztenciálisan leköt” (a szintaktikai folyamatban ez megfelelő pozíciók létre sem hozását jelenti); a végső szerkezet a (15c) példában ezt mondja tehát: „van valaki, aki ás valami anyagot, és van olyan 
gödör, amit létrehoz ezáltal - ebbe kerülnek a megnevezett kincsek, mindez pedig a megnevezett vezér akaratából történik így".

A szabad birtokosválasztás, amire például a (14d') esetében kerül sor, némileg másfajta jelentéshálózaton működik. E hálózat nyilván a bemondókkal asszociálható szereplőket tartalmaz. A bemondó mint alkalmazott például őt alkalmazó tévétársaságokkal asszociálódik (a hírek, a mikrofon és az esetleges rajongók mellett), az M99 tehát egy tévécsatorna lehet. Alberti (1995) vázolja fel egy ilyen hálózat karakterét. A fenti (15d) példa rokonítható esetet szemléltet: Vendel nyilván az ábrázolt jelentéshálózat Ágens szereplője, a villa szerepét pedig a hálózat alkalmi (aktuális) kibővítésével kell létrehozni (NB: a hálózat mentális kiépítése során is egy anyanyelvi beszélő (sikeres) alkalmi bővítéseket raktároz el). A jelentések ontológiába illeszkedése alapján az ásáshoz asszociálódva elérhető a munkavégzésekért kapható pénz mint világunk oly fontos szereplője, amiért pedig például szép villa vásárolható.

\section{A magyar „Split DP”}

A 2. szakaszban említett Átfogó magyar forrásnyelvtan kidolgozása során a magyar főnévképzők még egy érdekes szemantikai sajátosságára derült fény, amely összefüggésben áll a deverbális birtokszó és a birtokos kapcsolatának „elidegeníthetőségével”, vagyis gyengeségével, külsődlegességével. Mielőtt rátérnénk a részletekre, megjegyezzük, hogy ezt a szakaszt főként a magyar generatív szintaxisban járatos olvasóknak szánjuk.

Azok a képzett konstrukciók, amelyek megőrzik a bemeneti igei szerkezetet a (14) példában számba vett típusok közül abban az értelemben, hogy a főnévi szerkezetbe beágyazott VP-ben kifejezendő marad a Téma (ha volt egyáltalán), valamint ez a VP nem kerül egy olyan Posd operátor komplementumzónájába, amely „elidegeníthetőséget” fejez ki, akkor ennek az igei szerkezetnek az esetleges belső operátorviszonyai is kifejezhetőek („maradnak”) a képzett főnévi konstrukcióban. Úgy is fogalmazhatunk hogy a fentieknek megfelelő (14b, c, c', d, e, e') deverbális főnévi konstrukciók esetében az igei bemenet operátor-hatóköri viszonyrendszere „,beleöröklődik” a DP-n belüli operátorzóna-rendszerbe. A (17) példasorhoz kapcsolódó ábrához azt a megjegyzést füzzük, hogy az $\mathrm{N}$ fejben lévő képző komplementumzónájában egy vP kifejezést mutatunk be, de egyes elemzésekben VP, míg másokban AspP foglal itt helyet.

(16) a. Letartóztatták mindkét hír bemondóit.

a'. (?)Csak mindkét hír bemondóit tartóztatták le.

b. Letartóztatták mindkét csatorna bemondóit.

b'. *?Csak mindkét csatorna bemondóit tartóztatták le.
a. (?)Na például mindkét évben mindkét konferenciára ugyanannak a kutatónak az elküldését, azt meg fogom akadályozni.
a'. (?)Csak mindkét mentor(-nak a) protezsáltja nyerheti meg a versenyt.
a". Mindkét mentor(nak a) protezsáltja megnyerheti a versenyt.
b. (?)Mindkét konferenciára való elküldésedet meg fogom akadályozni.
b'. (?)A mindkét konferenciára való elküldésedet meg fogom akadályozni. 


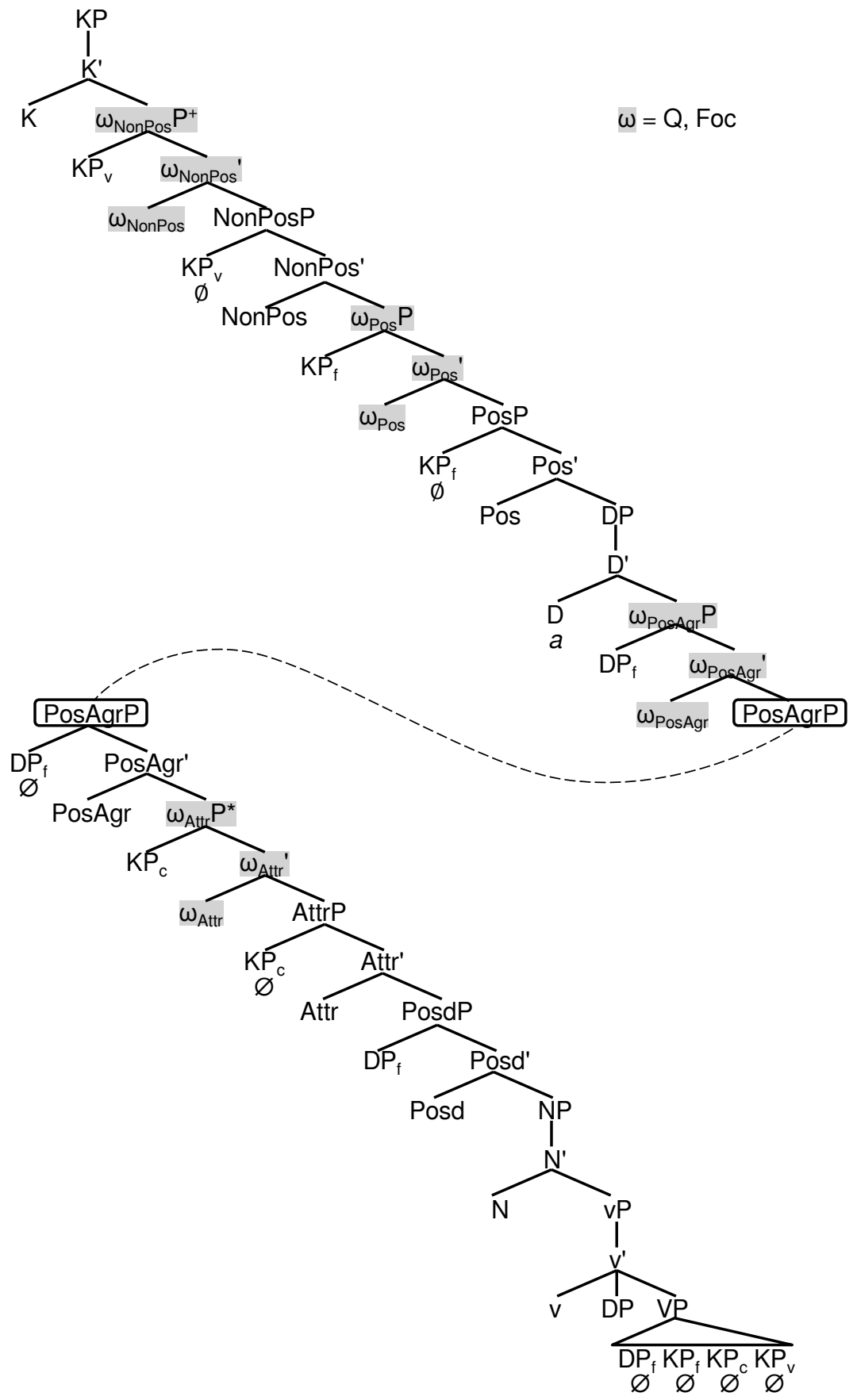


Létezik a DP-n belül operátorzóna-rendszer? A Szabolcsi-Bartos-É. Kiss-féle DPmodellben ${ }^{14}$ nem merül fel egy belső operátorzóna lehetősége. Pedig már Szabolcsi (1992) modellje arra az alapgondolatra épül, hogy a főnévi szerkezet a mondatszerkezet (CP) „másolata” - amit a „Split DP” hipotézis képviselői ${ }^{15}$ úgy általánosítanak, hogy a Rizzi-féle (1997) (kartografikus) mondatrétegződés a DP-szerkezetben is hasonlóan finom szerkezeti rétegződésben tükröződik vissza belső topikok és fókuszok megjelenésének a formájában.

A fenti (16) példasor az Ó-főnévképző (14d-d')-ben bemutatott kétféle változatán szemlélteti a képzés bemenetéül szolgáló igei konstrukció hatóköri viszonyainak öröklődését (16a-a'), illetve ennek az öröklődésnek a kizárt voltát (16b-b').

A (16a) mondat kétértelmű, hatóköri okokból kifolyólag. A kvantált birtokos (mindkét hír) értelmezhető a mondat igéjéhez képest, tehát széles hatókörrel: mindkét hír esetében letartóztatták annak bemondóit (vagyis azokat is letartóztatták, akik csak az egyik hírt mondták be). Ugyanez a kvantált birtokos viszont értelmezhető a főnévképzés bemenetéül szolgáló igéhez képest is, szűk hatókörrel: akadtak, akik mindkét hírt bemondták, és őket tartóztatták le (arról nem szól a mondat, hogy a csak az egyik hírt bemondó embereket letartóztatták-e). Kétségtelen, hogy a szük hatókört nehezebb elöhívni; ha azonban egy olyan teszthelyzetet alkalmazunk, mint a (16a') mondatban, amelynek lényege, hogy a főnévi szerkezet a mátrix igétől fókuszszerepet kap, akkor a vizsgált kvantált kifejezés számára csak a képzés bemenetéül szolgáló - beágyazott - igéhez képest értelmezhető kvantorjelentés marad. A (16a') tehát egyértelmű, és egyetlen jelentése a szűk hatókörü olvasat: kizárólag azokat tartóztatták le, akik mindkét hírt bemondták.

A (16b) mondat nem kétértelmü; csakis a széles hatókörü olvasata van meg: mindkét csatorna esetében fennáll, hogy letartóztatták a bemondóit. A potenciális szűk hatókörű olvasat esetén csak a bemondók egy szűkebb halmazát tartóztatták volna le, mégpedig azokat, akik valami módon egyszerre álltak volna mindkét csatorna alkalmazásában bemondóként. A (16b') mondathoz pedig nem rendelhető jelentés, mivel az adott teszthelyzetben fókuszszerep van a főnévi szerkezetre kényszerítve (ez lesz tehát a széles hatókör), a szűk hatókör pedig ki van zárva. Hogy miért is van kizárva? A szakasz elején megadott okokból kifolyólag: a (14d')ben bemutatott Ó*-főnévképző elnyomja, vagyis ki nem fejezendővé teszi a bemeneti ige Témáját, a birtokos pozíciójába pedig egy elidegeníthető szereplőt állít e Téma helyett (NB: a bemondója elidegeníthetetlen birtokosa a bemondott hír). Az igei bemenet operátor-hatóköri viszonyrendszere tehát - ahogy ott fogalmaztunk - nem tud „beleöröklődni” a DP-n belüli operátorzóna-rendszerbe.

A (14d)-ben bemutatott Ó-főnévképző tehát, az Ó* főnévképzővel ellentétben, „hagyja érvényesülni” a képzés bemenetén megjelenő VP karakterét, beleértve ebbe az információstruktúra lehetőségét is. Minderről egy olyan DP-modell képes számot adni, amely a Szabolcsi-Bartos-É. Kiss-féle struktúrába integrálja a „Split DP”-megközelítés lényegét jelentő operátorzónákat. Giusti (1996) konkrétan azt az univerzális hipotézist állítja fel, hogy akár a D fejhez tartozó héj alatt, akár afölött

\footnotetext{
${ }^{14}$ Ld. pl. Szabolcsi (1992), Szabolcsi-Laczkó (1992), Bartos (2000), É. Kiss (2002).

${ }^{15}$ Szláv és dél-európai nyelvek főnévi szerkezeteinek „Split DP”-megközelítését nyújtja például Giusti (1996), Insane-Puskás (2001), Caruso (2011), Cetnarowska (2014), Mišmaš (2014), Giusti-lovino (2014).
} 
kiépülhet operátorzóna a világ nyelveinek DP-szerkezeteiben; és mivel a DP természetesen más célokat is szolgál, mint az igei jellegzetességek befogadása, a nyelvek várhatóan eltérő mértékben kifejlett DP-n belüli operátorzónával rendelkeznek.

A magyar főnévi szerkezetben - méltó párjaként az igeinek - mind a $D$ fejhez tartozó héj alatt, mind afölött kiépülhet operátorzóna, ráadásul duplán: külön a birtokosnak, és külön az igétől örökölhető nem-birtokos vonzatnak. A (16)-(17) példasorokhoz tartozó általános szerkezet felülről lefelé haladva a következő négy operátorzónát tartalmazza tehát:

(i) Az $\omega_{\text {NonPos }} P$ operátorhéj például (ahol, mint az ábra mellett jeleztük, az $\omega$ operátort fókusznak vagy kvantornak választhatjuk) a fenti (17a) mondatnak a két kvantált kifejezését fogadja be (két ezek számára kiépülő $Q_{\text {NonPos }} P$ operátorhéjba), összhangban a szűk hatókörű olvasattal: azt akadályozza meg a beszélő, hogy mindkét évben mindkét konferenciára ugyanazt küldjék el; a két kvantált kifejezés tehát a beágyazott elküld igéhez képest értendő.

(ii) Ugyanebben a mondatban a fókuszált kifejezést (ugyanannak a kutatónak) az $\omega_{\text {Pos }} \mathrm{P}$, azaz ez esetben az $\mathrm{F}_{\mathrm{Pos}} \mathrm{P}$ operátorhéj fogadja be; a szük hatókörü olvasatot ezúttal az teszi egyértelmúvé, hogy a szóban forgó főnévi szerkezet a mátrix szerkezetben kontrasztív topik szerepet kap, melyet a Na például-konstrukció tesz egyértelművé (Alberti-Farkas-Szabó 2015). A (17a') példában a mindkét mentornak birtokosváltozat ugyancsak az $\omega_{\text {Pos }} P$ (ez esetben $Q_{\text {Pos }} P$ ) héjban foglal helyet, míg a mindkét mentor birtokosváltozat az alábbi harmadik operátorzónában áll.

(iii) Az említett zóna az $\omega_{\text {PosAgr }} P$ héj, amely immár a határozott névelő pozíciója után áll (NB: a PosAgrP héj a Szabolcsi-Bartos-É. Kiss-modellben annak a pozíciónak felel meg, ahol a birtokos egyeztetése ellenőrzésre kerül). Megjegyezzük, hogy (16a, a'), (17a'), illetve (17a") mondatok szük hatókörü értelmezése esetén is az $\omega_{\text {Pos }} P$ héjba kerül a birtokos, bár (17a") esetében ez az értelmezés csak nehezen hívható elő.

(iv) Az $\omega_{\text {Attr }} P$ operátorhéj betöltésére a (17b') mondat kvantora szolgáltat példát: ezúttal egy jelző(sített kifejezés) értelmezendő a beágyazott ige operátoraként: a beszélő ez esetben azt akadályozza meg, hogy elküldjenek valakit mindkét konferenciára.

Érdemes ezt a jelentést rögtön összevetni a (17b) széles hatókörű olvasatával, miszerint mindkét konferencia esetében megakadályozza a szigorú beszélő valakinek az elküldését. Mivel ezúttal a kvantor a finit igéhez tartozik, annak információszerkezetén belül épül ki kvantorhéj, míg a DP-n belül nem épül ki operátor jellegű $\omega_{\text {Attr }} P$ (jelen esetben $Q_{\text {Attr }} P$ ), hanem egyszerüen a jelzők AttrP héja fogadja be $a$ kvantort.

Ugyanilyen alapon állítjuk, hogy a (16a, b), valamint a (17a") mondat széles hatókörű olvasatáról úgy adhatunk számot, hogy a teljes főnévi szerkezet az ige információszerkezetében kiépülő kvantorhéjban jelenik meg, míg a konkrét kvantált kifejezéseket a DP-n belül PosAgrP héjba helyezzük, illetve a (17a") mindkét mentornak birtokosváltozata a PosP héjba helyezendő. ${ }^{16}$

${ }^{16}$ A PosP fölötti NonPosP héj vajon betölthető-e igei operátorfunkcióval bíró összetevővel? Igen, például a következő kérdéskonstrukció így elemzendő ama olvasata esetén, amikor egyetlen eseményt várunk válaszként (ez szokott lenni a tükörfókuszos változat, Id. (AlbertiMedve 2000), nem pedig pár-listát (kvantorfunkciójú első kérdőszóval): (?)Melyik konferenciára 
Az éles szemű olvasónak feltűnhetett, hogy a kizárólag széles hatókörű olvasattal rendelkező (17b) mondat és a kizárólag szűk hatókörű olvasattal rendelkező (17b') mondat között az a(z) határozott névelő implicit versus explicit jelenléte tesz különbséget. Az iménti megfogalmazás kétségkívül nem elfogulatlan, hanem már a megoldási javaslatunkat sugallja, mely szerint a magyarban (még mindig) csak részlegesen ölt hangalakot a határozott névelö (mintha még nem teljesen léptünk volna túl az ősi névelőtlenségen). A (17a'-a") minimálpár esetében, ha a jelöletlen birtokost tekintjük, akkor a névelö egyik esetben sem ölthet hangalakot - minden bizonnyal éppen a birtokos jelenlétéből adódóan, melynek az uráli nyelvekben általában determináló szerepe van (Fokos 1960: 232). A (17b-b') minimálpár esetében viszont - ahol nincs főnévi szerkezettel kifejezett birtokos, csak jelző - opcionális a névelő testet öltése. A névelő explicitté (nem) tétele azt a megkülönböztető szerepet nyeri tehát el, hogy amikor hangalakot ölt a névelő (17b'), akkor „útját állja” a véges igétől esetlegesen kívülről érkező operátorjegynek, és így marad tehát a belső hatókör; míg a „láthatatlanul” maradó névelő utat enged a véges igétől kívülről kapható kvantorjegynek (17b).

Akár három jelentést is felvehet ilyen okok miatt egy-egy mondat; ezt szemléltetjük a (18) példasorral. A (18a) mondat egyik jelentése úgy áll elö, hogy mindkét kvantorkifejezést a beágyazott ige operátorrendszerébe tartozónak tekintjük; ilyenkor a $Q_{\text {PosAgr }} P$-héj és a $Q_{\text {Attr }} P$-héj fogadja be az illető kvantorokat (18b). A (18a) mondat másik jelentése úgy áll elő, hogy mindkét kvantorkifejezést a véges ige operátorrendszerében vesszük figyelembe; ilyenkor a releváns kifejezések a PosAgrP-héjban és az AttrP-héjban jelennek meg a DP-n belül (18b'). Végül nincs kizárva az a vegyes megoldás sem, hogy a birtokos az igétöl, a nem-birtokosi bővítmény pedig a deverbális főnévtől kap kvantorfunkciót (18b"); a szerkezetben tehát a birtokos a PosAgrP-héjban van, minthogy „kívülről” kapja az operátorfunkciót, a nem-birtokos viszont egy $Q_{\text {Attr }} P$ belső operátorhéjban áll. A potenciális (18c) olvasat ki van zárva, amit a következő szabálynak tulajdoníthatunk: a főnév operátorrendszerében „benn maradó” operátor nem uralhatja a külső operátorrendszerbe tartozó operátor(oka)t. Vizuálisan megragadva a tiltott helyzetet a következőképpen fogalmazhatunk: nem metszheti a külső operátorrendszer a belsőt, sőt tipikusan csak egy operátorrendszer épül ki (NB: mindazonáltal a (18b")-ben bemutatott „hibrid” hatókörű olvasat meglepően könnyen előhívható).

kinek az elküldését javasoltad?! A melyik konferenciára összetevő a NonPosP-héjba kerül tehát, a kinek pedig a PosP-héjba, mivel a kérdő kifejezések az ige operátorrendszerébe tartoznak („Rémlik, hogy egyszer javaslatot tettél valakinek egy konferenciára való elküldésére. Melyik is volt az a konferencia, és ki is volt az a szerencsés?”). Kérdéses még, hogy a melyik konferenciára összetevő nem „szökött-e ki” a vizsgált DP-böl. Nos, onnan gondolhatjuk, hogy nem szökött ki, hogy akkor a tükörfókuszos változat így hangzana (amúgy szintén helyesen, persze gondosan kivitelezett hangsúlyozás esetén): (?) Melyik konferenciára javasoltad kinek az elküldését?! A (?) Melyik konferenciára kinek az elküldését javasoltad?! kérdés tükörfókuszos értelmezésű változatát tehát hamelni patkányfogással ('pied-piping') lehet megmagyarázni: a birtokos nem veszi fel „tükörfókuszos” helyzetét (csupán annak hangsúlyát ölti fel), hanem a ragos birtokosok megszokott helyén marad. 
(18) a. Mindkét kolléga mindkét konferenciára való elküldését ellenzem.

b. „Az azért túlzás, hogy mindkét kolléga mindkét konferenciára elmenjen. Legfeljebb három konferenciarészvételre van pénz."

b'. „Mindkét kolléga esetében ellenzem mindkét konferencia meglátogatását. Egyik kolléga se menjen el egyik konferenciára se!"

b". „Félreértés, hogy csak Béla kollégád esetében ellenzem azt, hogy mindkét konferencián részt vegyen. Mindkét kolléga esetében ellenzem ezt, elfogultság nélkül."

c. „Félreértés, hogy csak az egyik konferencia esetében ellenzem azt, hogy mindkét kolléga elmenjen oda. Mindkét konferencia esetében ellenzem ezt, nem teszek különbséget a két konferencia között."

\section{6. Összefoglalás}

A tanulmányunk címében nevesített -j- képzőröl, amelyben den Dikken (2015) az elidegeníthető birtoklás kifejezőjét lát(tat)ja, kimutattuk, hogy más formában létezik. Abból indultunk ki, hogy a magyar főnevek legtöbbjének a fonotaktikai felépítése (nagyjából a nem szibilánsra végződőeké) megengedi egy (a 2. szakaszban definiált) potenciális reguláris birtokszóváltozat létrehozását, ami az említett -j- komponenst valóban tartalmazza. Mivel azonban a -j-komponenst sok esetben a lexikalizálódott birtokszó-alternatívák is tartalmazzák (vö. ajtója ajtaja), az elidegeníthető birtoklásra vonatkozóan úgy mondhatunk ki hatékony szabályt (Id. (2)), ha az a potenciális reguláris birtokszóváltozat fogalmára épül.

A 3. szakaszban mutattuk be azt a jelenséget, amely a cikk alapgondolatát képezi: az Amerika felfedezte(kor) és a Péter felfedezettje birtokos szerkezetek között a döntő formai különbség éppen a fent említett, elidegeníthetőségért felelös -j-komponensben rejlik, ami éppen akkor jelenik meg, amikor a birtokos a birtokszó igei tövének Ágense.

A 4. szakaszban kifejtettük e megfigyelés univerzális jelentőségét, és kimondtuk az általánosítást, mely szerint a magyarban az igéből képzett főnevek valamennyi típusában teljesül a 2. szakaszban felállított (2) szabály, amennyiben az „elidegeníthetőséget” a deverbális főnevekkel alkotott birtokos szerkezetek körében az igei tő és a birtokos ágentív vagy „még lazább” kapcsolatában határozzuk meg (ahol a szoros kapcsolatot az ige és a hozzá téma szerepben társuló vonzat viszonya jelenti).

Az 5. szakaszt annak bemutatására szántuk, hogy a magyar főnévi szerkezet generatív szintaktikai modelljének továbbfejlesztésében hogyan kamatoztathatjuk a deverbális főnevekkel alkotott birtokos szerkezetekről megállapított összefüggéseket, különös tekintettel bizonyos hatóköri többértelműségekre, amelyek lényegében akkor állnak fenn, amikor a deverbális főnév mint birtokszó „szoros” kapcsolatban áll birtokosával.

\section{Köszönetnyilvánítás}

A tanulmány elkészítésekor az OTKA NK 100804 „Átfogó magyar nyelvtan” projekt támogatását élveztük. Az elkészült tanulmányt a szerzők a Pécsi Tudományegyetem alapítása 650. évfordulója emlékének szentelik. 


\section{Hivatkozások}

Alberti, Gábor 1995. Role assignment in Hungarian possessive constructions. In István Kenesei - Csaba Pléh (szerk.) Approaches to Hungarian 5. Levels and Structures. Szeged: JATE. 13-28.

Alberti Gábor 2006. A szóképzéssel együttjáró vonzatszerkezet-változások rendszere. Nyelvtudományi Közlemények 103:75-105.

Alberti Gábor 2009. A szóképzéssel együttjáró vonzatszerkezet-változások egy polaritásérzékeny rendszere. In Fancsaly Éva (szerk.) Tanár és tanítvány. Írások Györke József és Hajdú Péter tiszteletére (2002-2007). (Studia Linguistica). Budapest, Pécs: Dialóg Campus. 122-145.

Alberti Gábor 2013. Az argumentumok precedenciaelvű realizálódása. In Szilágyi N. Sándor - Kádár Edit (szerk.) Analógia és modern nyelvleírás. Kolozsvár: Erdélyi Múzeum-Egyesület Kiadó. 9-41.

Alberti Gábor - Farkas Judit 2013. Vonzóak-e a magyar főnevek? In Benő Attila Fazakas Emese - Kádár Edit (szerk.) „...hogy legyen a víznek lefolyása...” Köszöntő kötet Szilágyi N. Sándor tiszteletére. Kolozsvár: Erdélyi MúzeumEgyesület Kiadó. 17-29.

Alberti, Gábor - Judit Farkas - Veronika Szabó 2015. Arguments for arguments in the complement zone of the Hungarian nominal head. In Katalin É. Kiss - Balázs Surányi - Éva Dékány (szerk.) Approaches to Hungarian 14. Amsterdam: John Benjamins Publishing Company. 5-36.

Alberti Gábor - Medve Anna 2002/2005. Generatív grammatikai gyakorlókönyv. Budapest: Janus/Books - Gondolat Kiadó.

Alberti, Gábor - Anna Medve 2000. Constituents in special operator positions. In Gábor Alberti - István Kenesei (szerk.) Approaches to Hungarian 7. Papers from the Pécs Conference. Szeged: JATEPress. 93-117.

Bárczi Géza - Benkő Lóránd - Berrár Jolán 1999. A magyar nyelv története. Budapest: Nemzeti Tankönyvkiadó.

Bartos Huba 2000. Az inflexiós jelenségek szintaktikai háttere. In Kiefer Ferenc (szerk.) Stukturális magyar nyelvtan 3. Morfológia. Budapest: Akadémiai Kiadó. 653-762.

Broekhuis, Hans - Evelin Keizer - Marcel den Dikken 2012. Syntax of Dutch Nouns and Noun Phrases. Amsterdam: Amsterdam University Press.

Caruso, Durdica Zeljka 2011. Nominal phrases in Croatian as DPs. In Koichi Otaki - Hajime Takeyasu - Shin-ichi Tanigawa (szerk.) Online Proceedings of GLOW in Asia Workshop for Young Scholars 2011. Mie University, Japan. 16-30.

Cetnarowska, Bożena 2014. The topic phrase within a determiner phrase: Fronting adnominal genitives in Polish. In Ludmila Veselovská - Markéta Janebová (szerk.) Nominal Structures: All in Complex DPs. (Olomouc Modern Language Monographs 2). Olomouc: Palacký University. 147-161.

Davidson, Donald 1967. The logical form of action sentences. In Nicholas Rescher (szerk.) The Logic of Decision and Action. Pittsburgh: University of Pittsburgh Press. 81-95.

Dékány, Éva 2014. Argument structure and functional projections in Old Hungarian verbal gerunds. Acta Linguistica Hungarica 61/3:317-361. 
Dikken, Marcel den 2015. The morphosyntax of (in)alienably possessed noun phrases: The Hungarian contribution. In Katalin É. Kiss - Balázs Surányi - Éva Dékány (szerk.) Approaches to Hungarian 14. Amsterdam: John Benjamins Publishing Company. 121-145.

Dowty, David 1991. Thematic proto-roles and argument selection. Language 67/3: 547-619.

É. Kiss, Katalin 2002. The Syntax of Hungarian. Cambridge: Cambridge University Press.

É. Kiss, Katalin 2006. The function and the syntax of the verbal particle. In Katalin É. Kiss (szerk.) Event Structure and the Left Periphery. Studies on Hungarian. Dordrecht: Springer. 17-55.

É. Kiss, Katalin 2008. Free word order, (non)configurationality, and phases. Linguistic Inquiry 39/3:441-475.

Elekfi, László 2000. Semantic differences of suffix alternates in Hungarian. Acta Linguistica Hungarica 47:145-177.

Farkas Judit 2015. Esettanulmányok egy hatásláncok motiválta thematikus elméletben. In Kádár Edit - Szilágyi N. Sándor (szerk.) Motiváltság és nyelvi ikonicitás. Kolozsvár: Erdélyi Múzeum-Egyesület Kiadó. 187-216.

Fokos Dávid 1960. Uráli és altaji összehasonlító szintaktikai tanulmányok. Nyelvtudományi Közlemények 62/2:213-241.

Fu, Jingqi - Thomas Roeper - Hagit Borer 2001. The VP within process nominals: Evidence from adverbs and the VP anaphor do-so. Natural Language \& Linguistic Theory 19/3:549-582.

Giusti, Giuliana 1996. Is there a FocusP and a TopicP in the noun phrase structure? University of Venice Working Papers in Linguistics 6/2:105-128.

Giusti, Giuliana - Rossella lovino 2014. A Split-DP Hypothesis for Latin and ItaloRomance. In Ludmila Veselovská - Markéta Janebová (szerk.) Complex Visibles Out There. (Olomouc Modern Language Monographs 4). Olomouc: Palacký University. 127-143.

Haspelmath, Martin 2008. Syntactic Universals and Usage Frequency: 3. Alienable vs. inalienable possessive constructions. Előadás. Leipzig Spring School on Linguistic Diversity. Leipzig. https://goo.gl/Bch8Lc (2015. 9. 21.).

Insane, Tabea - Genoveva Puskás 2001. Specific is not definite. Generative Grammar in Geneva 2:39-54.

Kiefer, Ferenc 1985. Natural morphology. Acta Linguistica Hungarica 35:85-105.

Kiefer Ferenc 2000. Jelentéselmélet. Budapest: Corvina.

Kiefer Ferenc - Ladányi Mária 2000a. A szóképzés. In Kiefer Ferenc (szerk.) Strukturális magyar nyelvtan 3. Morfológia. Budapest: Akadémiai Kiadó. 137-164.

Kiefer Ferenc - Ladányi Mária 2000b. Morfoszintaktikailag semleges képzések. In Kiefer Ferenc (szerk.) Strukturális magyar nyelvtan 3. Morfológia. Budapest: Akadémiai Kiadó. 165-214.

Kratzer, Angelika 1996. Severing the external argument from its verb. In Johan Rooryck - Laurie Zaring (szerk.) Phrase Structure and the Lexicon. (Studies in Natural Language and Linguistic Theory 33). Dordrecht: Kluwer Academic Publishers. 109-137. 
Laczkó Tibor 2000. Az ige argumentumszerkezetét megőrző főnévképzés. In Kiefer Ferenc (szerk.) Strukturális magyar nyelvtan 3. Morfológia. Budapest: Akadémiai Kiadó. 293-407.

Laczkó, Tibor 2009. Relational nouns and argument structure: Evidence from Hungarian. In Miriam Butt - Tracy Holloway King (szerk.) Proceedings of the LFG09 Conference. Stanford: CSLI Publications. 399-419.

Lohndal, Terje 2012. Towards the end of argument structure. In Maria Cristina Cuervo - Yves Roberge (szerk.) The End of Argument Structure? Bingley: Emerald Group Publishing. 156-184.

Marantz, Alec 1984. On the Nature of Grammatical Relations. Cambridge: The MIT Press.

Mišmaš, Petra 2014. An argument for Wh-fronting in the Slovenian DP. In Ludmila Veselovská - Markéta Janebová (szerk.) Nominal Structures: All in Complex DPs. (Olomouc Modern Language Monographs 2). Olomouc: Palacký University. 175-191.

Oszoli Borbála 2014. A -hatnék deverbális fönévképző morfoszintaktikai jellemzése. Szakdolgozat. Pécs: PTE Nyelvtudományi Tanszék.

Parsons, Terence 1990. Events in the Semantics of English: A Study in Subatomic Semantics. Cambridge: The MIT Press.

Rebrus Péter 2013. Miért nincs j? In Benő Attila - Fazakas Emese - Kádár Edit (szerk.) „...hogy legyen a víznek lefolyása...” Köszöntő kötet Szilágyi N. Sándor tiszteletére. Kolozsvár: Erdélyi Múzeum-Egyesület Kiadó. 383-401.

Rizzi, Luigi 1997. The fine structure of the left periphery. In Liliane Haegeman (szerk.) Elements of Grammar. Handbook in Generative Syntax. Dordrecht: Kluwer Academic Publishers. 281-337.

Schirm Anita 2005. Az elidegeníthető és az elidegeníthetetlen birtoklás kifejezésmódjairól. Nyelvtudomány 1:155-169.

Szabolcsi Anna 1992. A birtokos szerkezet és az egzisztenciális mondat. Budapest: Akadémiai Kiadó.

Szabolcsi Anna - Laczkó Tibor 1992. A főnévi csoport szerkezete. In Kiefer Ferenc (szerk.) Strukturális magyar nyelvtan 1. Mondattan. Budapest: Akadémiai Kiadó. 181-298.

Tompa József 1959. A mehetnék(je) típusú főnevek leíró nyelvtani kérdései. Magyar Nyelv 55/4:481-488.

Tompa József 1961. A mehetnék(je) típusú deverbalis főnevek mai változataihoz. Magyar Nyelv 57/3:340-342. 


\section{A szerzőkről}

Alberti Gábor (DSc) egyetemi tanár a Pécsi Tudományegyetemen, ahol a Nyelvtudományi Tanszéket vezeti, valamint a ReALIS Elméleti, Számítógépes és Kognitív Nyelvészeti Kutatócsoportot. Formális, lexikai és diskurzusszemantikai kutatásokon kívül a magyar nyelv generatív szintaktikai leírásában is részt vesz, jelenleg az MTA Nyelvtudományi Intézetében Kenesei István által vezetett Átfogó magyar nyelvtan (Comprehensive Resource Grammars: Hungarian) OTKA-óriásprojekt tagjaként.

Elérhetősége: alberti.gabor@pte.hu

Farkas Judit (PhD) a Magyar Tudományos Akadémia Nyelvtudományi Intézetének a tudományos munkatársa. Jelenleg éppen az Átfogó magyar nyelvtan (Comprehensive Resource Grammars: Hungarian) OTKA-óriásprojekt tagjaként van alkalmazva, míg más időszakokban nyelvtörténeti projektekben dolgozik. Állandó óraadó, illetve helyettesítő tanár a Pécsi Tudományegyetem Nyelvtudományi Tanszékén. A magyar generatív nyelvészet eredményeinek a közoktatásba való integrálásán is munkálkodik.

Elérhetősége:juttasusi@gmail.com 